\title{
GROWTH RINGS IN CERRADO WOODY SPECIES: OCCURRENCE AND ANATOMICAL MARKERS.
}

\author{
Carmen Regina Marcati ${ }^{1,3}$, Julia Sonsin Oliveira ${ }^{1}$ \& Silvia Rodrigues Machado ${ }^{2}$
}

Biota Neotropica v6 (n3) -http://www.biotaneotropica.org.br/v6n3/pt/abstract?article+bn00206032006

Date Received 08/08/2005

Revised 08/18/2006

Accepted 09/01/2006

(1) Departamento de Recursos Naturais - Ciências Florestais, Universidade Estadual Paulista (UNESP), Botucatu, SP, CP 237, CEP 18603-970, Brazil.

(2) Departamento de Botânica, Instituto de Biociências, Universidade Estadual Paulista (UNESP), Botucatu, SP, CP 510, CEP 18618-000, Brazil.

(3) Corresponding author: E-mail: carmen@fca.unesp.br. Phone and fax: +55 01438117168

\begin{abstract}
Marcati, C.R.; Oliveira, J.S. and Machado, S.R. Growth rings in cerrado woody species: occurrence and anatomical markers. Biota Neotrop. Sep/Dez 2006 vol. 6, no. 3 http://www.biotaneotropica.org.br/v6n3/pt/abstract?article+bn00206032006 ISSN 1676-0611

Growth ring occurrence was investigated in 48 representative species of cerrado in the state of São Paulo, Brazil. We characterized growth ring markers and described the growth layer structure of the basal portion of the most developed stem branches in woody plants. Growth rings were poorly defined in 33\%, well defined in $61 \%$ and not discernable in $6 \%$ of the species studied. Various anatomical features were used as growth markers, such as: thick-walled latewood fibres; radially flattened latewood fibres; fibre zones; distended rays; marginal bands of axial parenchyma; marginal lines of parenchyma; and closeness of the narrow bands of scalariform parenchyma. In a single species, different growth ring markers often occurred together. Within growth layers, variations in the anatomical features were observed. Variations in the axial parenchyma distribution within growth rings in Vochysia cinnamomea, Qualea multiflora, V. rufa and V. tucanorum, wood are here reported for the first time. Variation in the distance of the axial parenchyma in narrow bands along the rays within growth layers in Annona coriacea, A. crassiflora, Diospyrus hispida and Roupala montana wood is also reported. Phenology and habit of the studied species were important aspects related to both growth ring presence and distinctness as well as to the anatomical features' variations within growth layers.
\end{abstract}

Key words: Cerrado, increment zones, habit, phenology, wood anatomy

\section{Resumo}

Marcati, C.R.; Oliveira, J.S. and Machado, S.R. Camadas de crescimento em espécies lenhosas de cerrado: ocorrência e marcadores anatômicos. Biota Neotrop. Sep/Dez 2006 vol. 6, no. 3 http://www.biotaneotropica.org.br/v6n3/pt/ abstract?article+bn00206032006 ISSN 1676-0611

Este estudo investigou a ocorrência de camadas de crescimento em 48 espécies representativas de cerrado no estado de São Paulo, Brasil. Amostras foram obtidas da porção basal de ramos caulinares mais desenvolvidos. Foram caracterizados os marcadores de crescimento, bem como foi descrita a estrutura das camadas de crescimento. As camadas de crescimento apresentaram-se mal definidas em 33\% e bem definidas em $61 \%$, sendo ausentes em $6 \%$ das espécies analisadas. Várias características anatômicas foram utilizadas como marcadores de crescimento, tais como: fibras de paredes espessas; fibras achatadas radialmente, zonas fibrosas; raios distendidos; faixas marginais de parênquima axial; linhas de parênquima marginal; e proximidade das linhas de parênquima escalariforme. Diferentes marcadores podem ocorrer em uma mesma espécie. Variações na distribuição do parênquima axial nas camadas de crescimento em Vochysia cinnamomea, Qualea multiflora, V. rufa and V. tucanorum, bem como variação na distância das linhas de parênquima axial ao longo dos raios dentro das camadas de crescimento em Annona coriacea, A. crassiflora, Diospyrus hispida e Roupala montana são aqui reportadas pela primeira vez. A fenologia e o hábito das espécies foram aspectos importantes relacionados tanto com a presença e nitidez das camadas de crescimento no lenho quanto com as variações dentro dessas camadas.

Palavras-chave: anatomia da madeira, zonas de incremento, cerrado, fenologia, hábito.

http://www.biotaneotropica.org.br 


\section{Introduction}

Cerrado plants are characterized by slow secondary growth due to diverse factors including limited water availability during the dry season, high irradiation levels, low fertility and acidic soil, high incidence of herbivores and periodic fires (Coutinho 1990, Franco 2002). Additionally, these plants have small size and genuine morphological characteristics such as scleromorphic leaves, and twisted trunks and branches which give a tortuous aspect to the vegetation; however straight trunks may occur in tall trees (Eiten 1993).

The internal structure of cerrado plants is strongly affected by the environmental factors and most of the studies considering the interaction between these factors and plant anatomy have been conducted with leaf (Morretes \& Ferri 1959, Morretes 1967, 1969, Oliveira \& Marquis 2002). Regarding to the wood features, which are affected mainly by water availability (Franco 2002), the reports are restricted to a few species and have come mainly from studies on mature wood of the main trunk (Machado \& AngyalossyAlfonso 1995, Ceccantini 1996, Machado et al. 1997, Marcati et al. 2001, Machado et al. in press). Growth rings occurrence in cerrado plants was reported in a few species by Coradin (2000) and Tomazello et al. (2004). However, growth rings in these plants are very irregular and with poorly defined boundaries (Coradin 2000).

Growth rings studies are of interest to climatology, as a hydrologic register; to dendrochronology, to estimate the age of trees; to ecology, to recuperate data on fire history; to paleoclimatology; to analyze growth dynamics, and to various other practical applications (see Baas \& Vetter 1989, Eckstein et al. 1995, Coradin 2000).

The goal of this study was to verify the occurrence of growth rings in 48 representative species of well-preserved remnants of cerrado in the state of São Paulo, Brazil. We characterized growth ring markers and described the growth layer structure. The analyses were conducted in stem branches because destructive methods were not allowed.

\section{Material and Methods}

The study was carried out in a well-preserved remnant area of cerrado located in the west central part of the state of São Paulo, Brazil ( $\left.22^{\circ} 55^{\prime} \mathrm{S}, 48^{\circ} 30^{\prime} \mathrm{W}\right)$. We studied 48 trees and shrubs species belonging to 27 angiosperm families. Precipitation and temperature data of the region studied were obtained from the Natural Resources Department Agrometeorological Station, São Paulo State University (UNESP). The vouchers and samples of one specimen from all the species are deposited, respectively, in the Herbarium (BOTU) and in the Wood Collection (BOTw) of the Natural Resources Department, University of the State of São Paulo (Table 1). The family classification follows APGII (Souza \& Lorenzi 2005).
Discs of $3 \mathrm{~cm}$ in thickness were obtained from the basal portion of the most developed branches (three sampled plants, one branch per plant). For macroscopic analyses, the cross sections were polished with sandpaper and analysed under a stereomicroscope. For microscopic analyses, a sliding microtome was used to cut transverse, radial, and tangential sections of $15-20 \mu \mathrm{m}$ in thickness, which were double-stained with safranin and astra blue (Roeser 1972) and mounted permanently in Entellan synthetic medium.

Due to observation of the entire circumference of the discs, the term "growth ring" was used in this study. The analyses were qualitative and followed IAWA Committee (1989) instructions. The term fibre zone, adapted from IAWA Committee (1989), was used here when a distinct decreasing in frequency of vessels and parenchyma was observed in the entire circumference of the branches. On a macroscopical level, such a zone always appeared darker-colored.

The leaf fall pattern of the studied species were classified into evergreen, semi-deciduous and deciduous, according to phenological observations which were carried out weekly during two years (2002-2004). Habit was classified into shrubs, small trees (seemingly shrubs in size, however with just one slender trunk), trees (with a well-developed trunk and crown) and tall trees (emergents with crown above dossel), adapted from Ribeiro et al. (1999).

\section{Results}

The climate diagram shows one annual dry season per year in the studied region (Figure 1).

Growth rings were not discernable in $6 \%$ of the species studied, were poorly defined in 33\% and were well defined in $61 \%$ (Table 1). Among the species with growth rings in their wood, $63 \%$ of them are semi-deciduous or deciduous (56,5\% semi-deciduous, $6,5 \%$ deciduous) against $37 \%$ evergreen (Table 1). The figure 2 shows the percentage of species lacking growth rings and with poorly defined and well-defined growth rings, within each phenological category.

Regarding to habit, growth rings are present in $83,3 \%$ of the shrubs and small trees and in $100 \%$ of the trees and tall trees (Table 1). Figure 3 shows the percentage of species lacking growth rings, species with poorly defined and well-defined growth rings within each habit category.

The growth ring markers and variations within growth rings of each of the studied species (Figures 4a-41b) are described in Table 2. The growth ring markers were observed as follows: thick-walled latewood fibres; radially flattened latewood fibres; fibre zones; distended rays; marginal bands of axial parenchyma; marginal lines of axial parenchyma; and closeness of the narrow bands of scalariform parenchyma. In a single species, different growth ring markers often occurred together. In the species with growth rings, the most common markers were thick-walled and radially flattened fibres and fibre zones (62\% of the species), followed 
Table 1. Growth rings of the studied species from Brazilian cerrado. $\boldsymbol{H}=$ habit. $T=$ tree. $S T=$ small tree. TT = tall tree. $S=$ shrub $($ Ribeiro, 1999 , adapted). $\boldsymbol{P h} \boldsymbol{B}=$ phenological behavior (field observation). $E=$ evergreen. $S D=$ semi-deciduous. $D=$ deciduous. $\mathbf{G R}=G r o w t h$ rings: $W=$ well defined; $P$ = poorly defined; $A=$ absent.

\begin{tabular}{|c|c|c|c|c|c|}
\hline Family & Species & BOT $_{w}$ & $\mathbf{H}$ & PhB & GR \\
\hline Anacardiaceae & Tapirira guianensis Aubl. & 1321 & $\mathrm{~T}$ & $\mathrm{E}$ & $\mathrm{P}$ \\
\hline \multirow[t]{2}{*}{ Annonaceae } & Annona coriacea Mart. & 1322 & ST & $\mathrm{SD}$ & $\mathrm{W}$ \\
\hline & Annona crassiflora Mart. & 1323 & ST & SD & $\mathrm{P}$ \\
\hline Araliaceae & Didymopanax vinosum (Cham. \& Schlecht.) March. & 1324 & $\mathrm{~S}$ & $\mathrm{E}$ & $\mathrm{P}$ \\
\hline \multirow[t]{2}{*}{ Asteraceae } & Gochnatia barrosii Cabrera & 1325 & $\mathrm{~S}$ & $\mathrm{E}$ & $\mathrm{W}$ \\
\hline & Piptocarpha rotundifolia Baker & 1326 & $\mathrm{~S}$ & $\mathrm{E}$ & $\mathrm{W}$ \\
\hline Bombacaceae & Eriotheca gracilipes (K. Schum.) A. Robyns & 1327 & $\mathrm{~T}$ & SD & $\mathrm{P}$ \\
\hline Boraginaceae & Cordia sellowiana Cham. & 1328 & $\mathrm{~T}$ & SD & $\mathrm{W}$ \\
\hline Caryocaraceae & Caryocar brasiliense Cambess. & 1331 & $\mathrm{~T}$ & $\mathrm{E}$ & $\mathrm{P}$ \\
\hline \multirow[t]{2}{*}{ Chrysobalanaceae } & Couepia grandiflora (Mart. \& Zucc.) Benth \& Hook. f. & 1332 & $\mathrm{~T}$ & SD & $\mathrm{W}$ \\
\hline & Licania tomentosa (Benth.) Fritsch. & 1333 & $\mathrm{~T}$ & $\mathrm{E}$ & $\mathrm{W}$ \\
\hline Clusiaceae (Guttiferae) & Kielmeyera rubriflora Cambess. & 1334 & ST & SD & $\mathrm{W}$ \\
\hline Combretaceae & Terminalia brasiliensis Raddi & 1335 & $\mathrm{~T}$ & $\mathrm{D}$ & $\mathrm{W}$ \\
\hline Ebenaceae & Diospyrus hispida DC. & 1336 & $\mathrm{~S}$ & $\mathrm{D}$ & W \\
\hline \multirow[t]{2}{*}{ Erythroxylaceae } & Erythroxylum suberosum A. St.-Hill. & 1337 & $\mathrm{~S}$ & $\mathrm{D}$ & A \\
\hline & Erythroxylum tortuosum Mart. & 1338 & $\mathrm{~S}$ & $\mathrm{D}$ & $\mathrm{P}$ \\
\hline Euphorbiaceae & Pera glabrata (Schott.) Bail. & 1339 & TT & $\mathrm{E}$ & $\mathrm{P}$ \\
\hline \multirow[t]{2}{*}{ Fabaceae - Caesalpinioideae } & Copaifera langsdorffii Desf. & 1330 & TT & SD & W \\
\hline & Dimorphandra mollis Benth. & 1351 & ST & SD & $\mathrm{P}$ \\
\hline Fabaceae - Cercideae & Bauhinia rufa (Bong.) Steud. & 1329 & $\mathrm{~S}$ & SD & $\mathrm{W}$ \\
\hline \multirow{3}{*}{ Fabaceae - Faboideae } & Bowdichia virgiloides Kunth. & 1340 & TT & SD & $\mathrm{W}$ \\
\hline & Machaerium villosum Vog. & 1341 & TT & $\mathrm{E}$ & $\mathrm{W}$ \\
\hline & Sweetia subelegans Mohlenbr. & 1342 & ST & SD & W \\
\hline \multirow[t]{2}{*}{ Fabaceae - Mimosoideae } & Anadenanthera falcata (Benth.) Speg. & 1350 & TT & SD & $\mathrm{W}$ \\
\hline & Stryphnodendron polyphyllum Mart. & 1352 & ST & SD & $\mathrm{W}$ \\
\hline \multirow[t]{2}{*}{ Lauraceae } & Nectandra sp. & 1343 & $\mathrm{~T}$ & $\mathrm{E}$ & $\mathrm{W}$ \\
\hline & Ocotea corymbosa (Meisn.) & 1344 & $\mathrm{~T}$ & $\mathrm{E}$ & $\mathrm{P}$ \\
\hline \multirow[t]{3}{*}{ Malpighiaceae } & Byrsonima basiloba A. Juss. & 1345 & ST & SD & $\mathrm{P}$ \\
\hline & Byrsonima coccolobifolia Kunth. & 1346 & ST & $\mathrm{SD}$ & W \\
\hline & Byrsonima verbascifolia (L.) DC. & 1347 & ST & SD & $\mathrm{W}$ \\
\hline \multirow[t]{2}{*}{ Melastomataceae } & Miconia albicans $(\mathrm{Sw})$ Triana & 1348 & ST & $\mathrm{E}$ & A \\
\hline & Miconia ligustroides (DC.) Naudir. & 1349 & ST & $\mathrm{E}$ & W \\
\hline Myrsinaceae & Rapanea umbellata (Mart.) Mez. & 1353 & $\mathrm{~T}$ & $\mathrm{E}$ & $\mathrm{P}$ \\
\hline Ochnaceae & Ouratea spectabilis (Mart.) Engl. & 1354 & $\mathrm{~T}$ & SD & $\mathrm{P}$ \\
\hline Proteaceae & Roupala montana Aubl. & 1355 & ST & $\mathrm{E}$ & $\mathrm{W}$ \\
\hline Rubiaceae & Alibertia concolor (Cham.) K. Schum. & 1356 & $\mathrm{~S}$ & $\mathrm{E}$ & $\mathrm{W}$ \\
\hline Rutaceae & Zanthoxylum rhoifolium Lam. & 1357 & ST & $\mathrm{E}$ & $\mathrm{W}$ \\
\hline Sapotaceae & Pouteria torta (Mart.) Radlk. & 1358 & $\mathrm{~T}$ & SD & $\mathrm{W}$ \\
\hline \multirow[t]{2}{*}{ Styracaceae } & Styrax camporum Pohl. & 1359 & ST & $\mathrm{E}$ & $\mathrm{P}$ \\
\hline & Styrax ferrugineus Nees \& Mart. & 1360 & ST & $\mathrm{E}$ & $\mathrm{P}$ \\
\hline Tiliaceae & Luehea grandiflora Mart. & 1361 & $\mathrm{~T}$ & SD & $\mathrm{A}$ \\
\hline Verbenaceae & Aegiphilla sellowiana Cham. & 1362 & $\mathrm{~S}$ & SD & $\mathrm{W}$ \\
\hline \multirow{6}{*}{ Vochysiaceae } & Qualea dichotoma (Mart.) Warm. & 1363 & TT & SD & $\mathrm{P}$ \\
\hline & Qualea grandiflora Mart. & 1364 & $\mathrm{~T}$ & SD & $\mathrm{W}$ \\
\hline & Qualea multiflora Mart. & 1365 & $\mathrm{~T}$ & SD & $\mathrm{W}$ \\
\hline & Vochysia cinnamomea Pohl. & 1366 & $\mathrm{~T}$ & SD & $\mathrm{P}$ \\
\hline & Vochysia rufa Mart. & 1367 & TT & SD & $\mathrm{W}$ \\
\hline & Vochysia tucanorum Mart. & 1368 & $\mathrm{~T}$ & SD & $\mathrm{W}$ \\
\hline
\end{tabular}




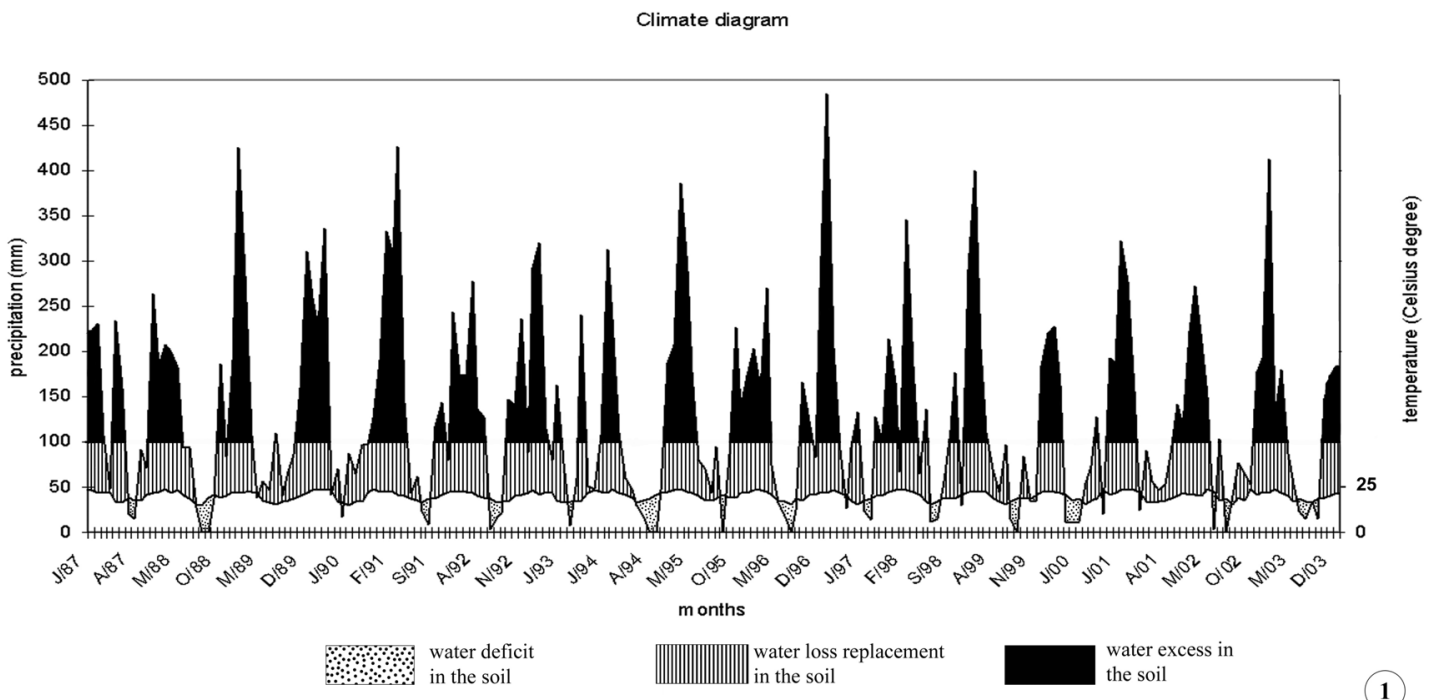

Figure 1. Climate diagram of the west central part of the state of S,o Paulo, according to Walter et al. (1975) methodology.

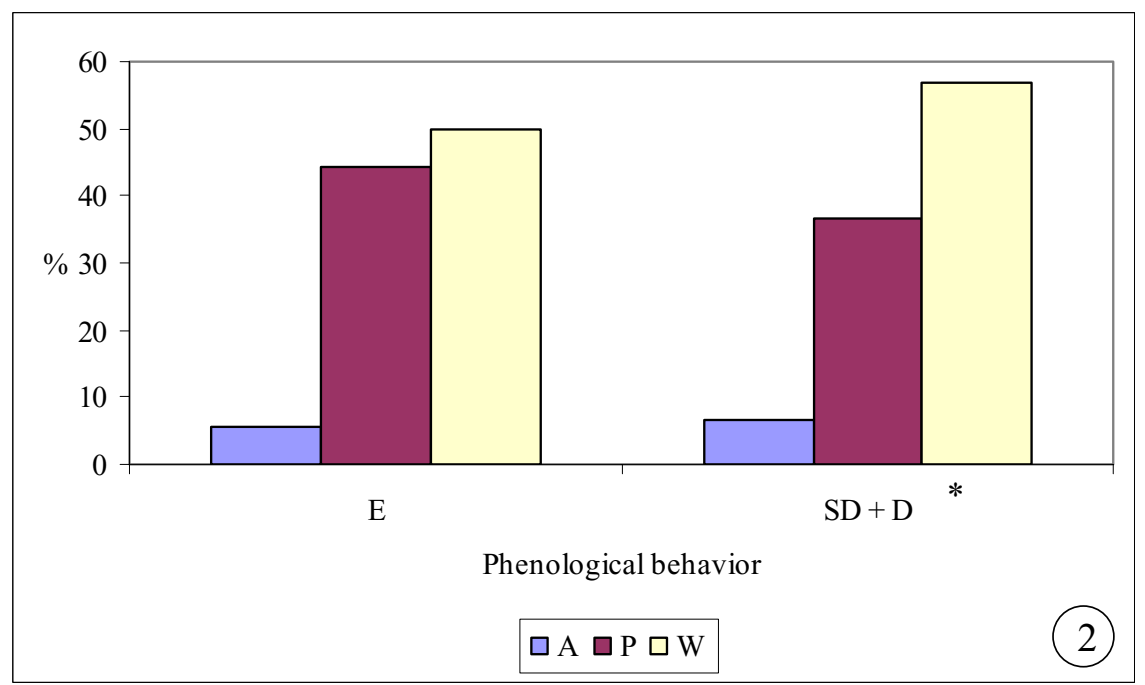

* as the number of deciduous species was small, deciduous and semi-deciduous species were pooled.

Figure 2. Percentage of species lacking growth rings, species with poorly defined and well-defined growth rings within each phenological category. As the number of deciduous species was small, deciduous and semi-deciduous species were pooled. $E=$ evergreen. SD $+D=$ semideciduous plus deciduous. $A=$ growth rings absence. $P=$ poorly defined growth rings. $W=$ well defined growth rings. 


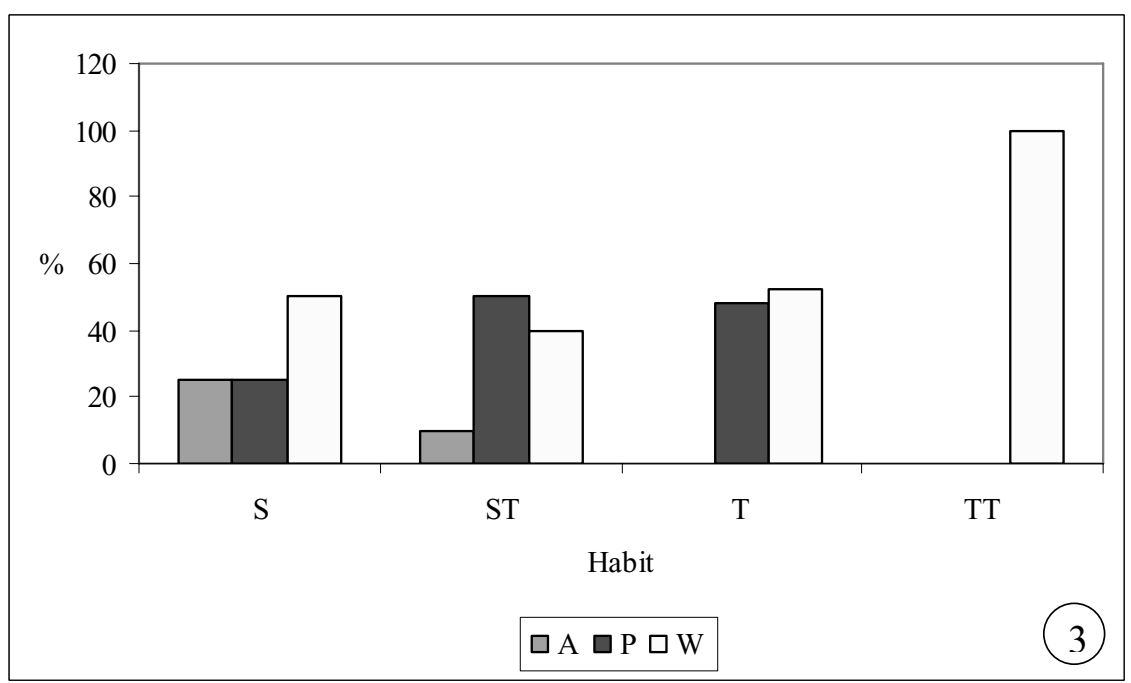

Figure 3. Percentage of species lacking growth rings, species with poorly defined and well-defined growth rings within each habit category. S = shrubs. $S T=$ small tree. $T=$ tree. $T T=$ tall tree. $A=$ growth rings absence. $P=$ poorly defined growth rings. $W=$ well defined growth rings.
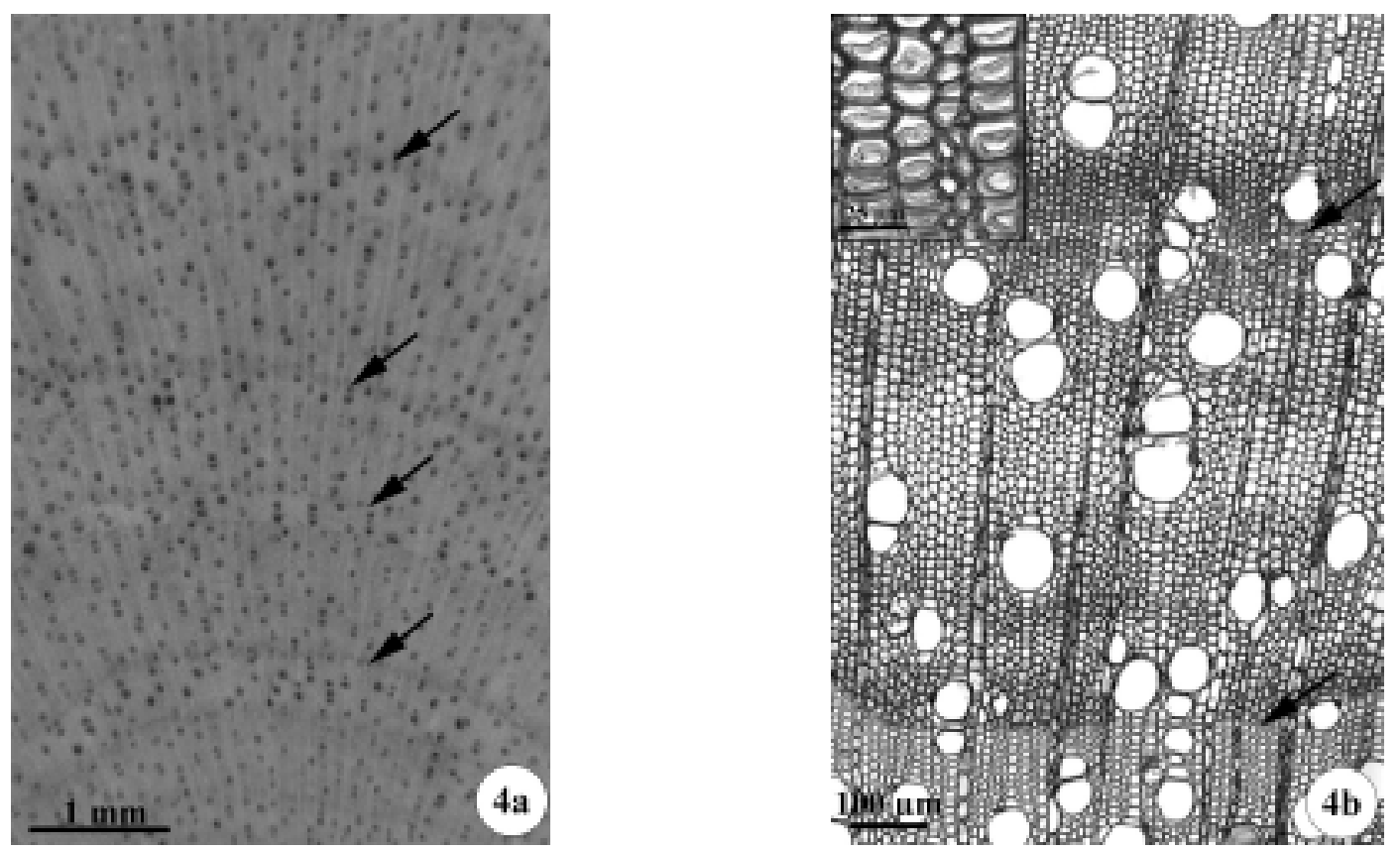

Figure 4. $a-b$. Transverse section of Nectandra sp. wood. a) Photomacrograph showing growth layers boundaries (arrows). b) Photomicrograph. Arrows indicate thick-walled and radially flattened latewood fibres. Gelatinous fibres occur along the growth layer and can be noted in detail above in the figure.

http://www.biotaneotropica.org.br 

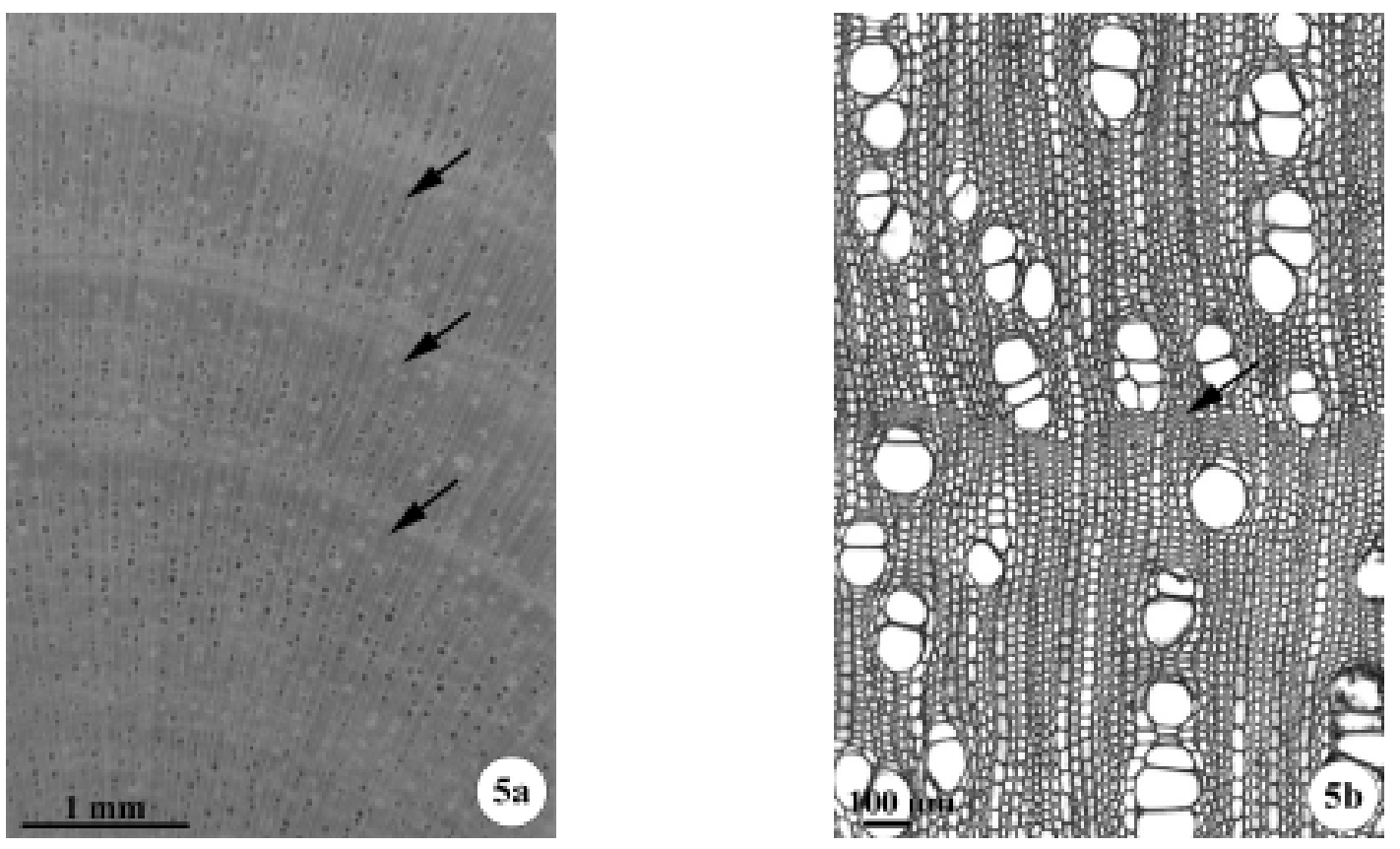

Figure 5. $a-b$. Transverse section of Miconia ligustroides wood. a) Photomacrograph. Arrows indicate growth layers boundaries. Parenchymalike fibre bands can be noted lighter in the figure. b) Photomicrograph. Arrow indicates thick-walled and radially flattened latewood fibres.
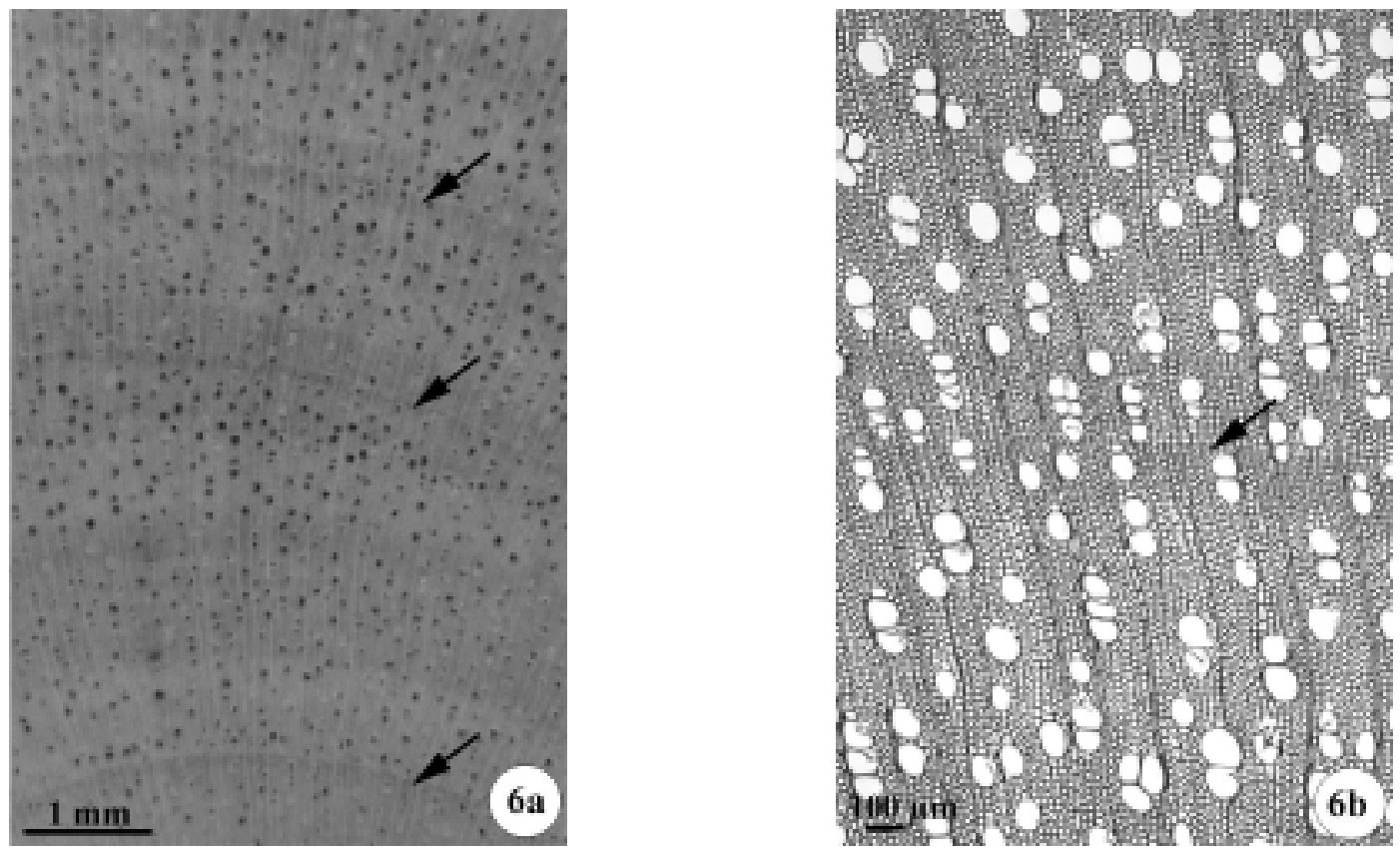

Figure 6. $a-b$. Transverse section of Zanthoxylum rhoifolium wood. a) Photomacrograph. Arrows indicate growth layers boundaries. b) Photomicrograph. Arrow indicates thick-walled and radially flattened latewood fibres.

http://www.biotaneotropica.org.br 
Marcati, C.R.; Oliveira, J.S. and Machado, S.R. - Biota Neotropica, v6 (n3) - bn00206032006
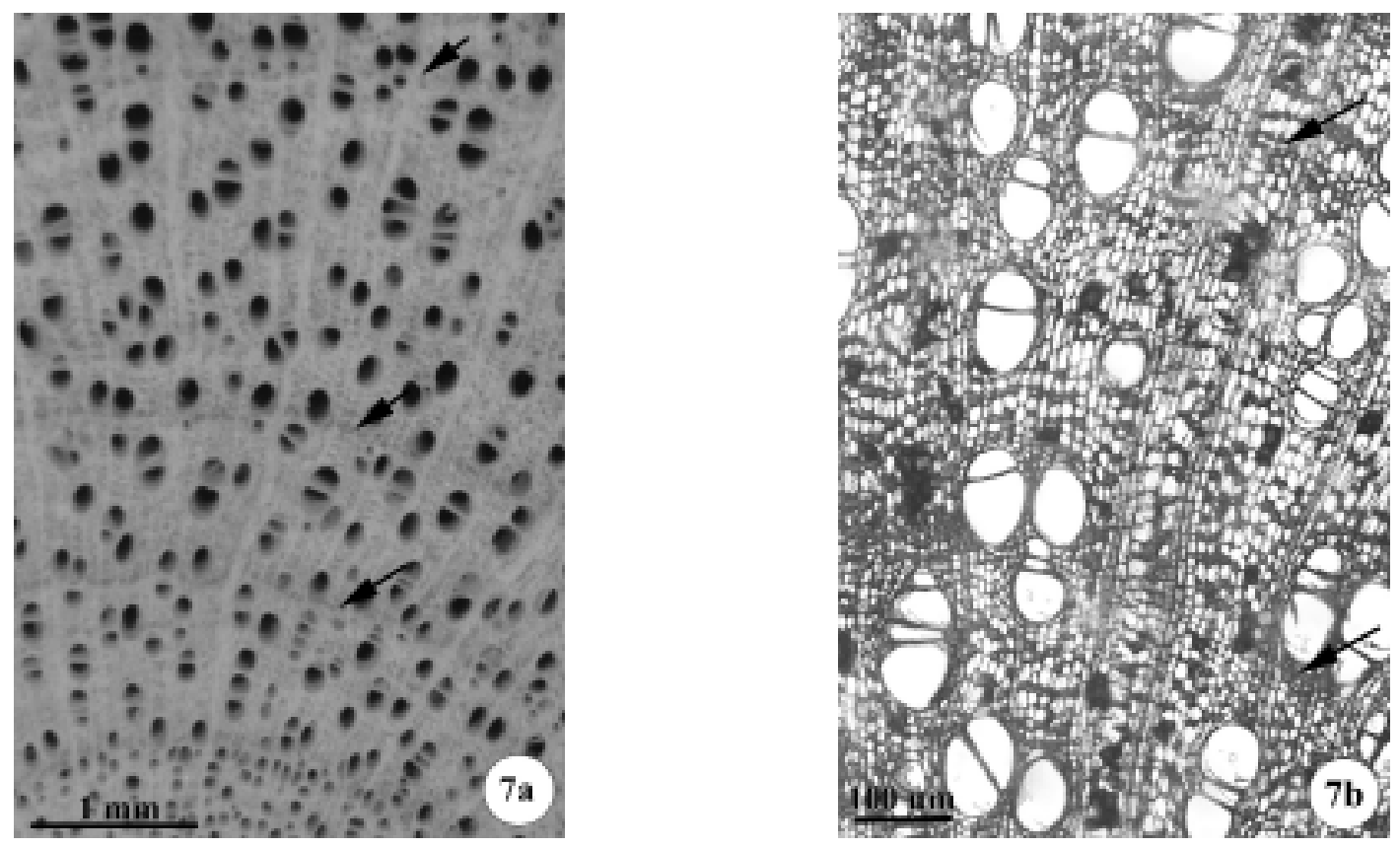

Figure 7. $a-b$. Transverse section of Eriotheca gracilipes wood. a) Photomacrograph. Arrows indicate growth layers boundaries. b) Photomicrograph. Arrows indicate thick-walled and radially flattened latewood fibres.
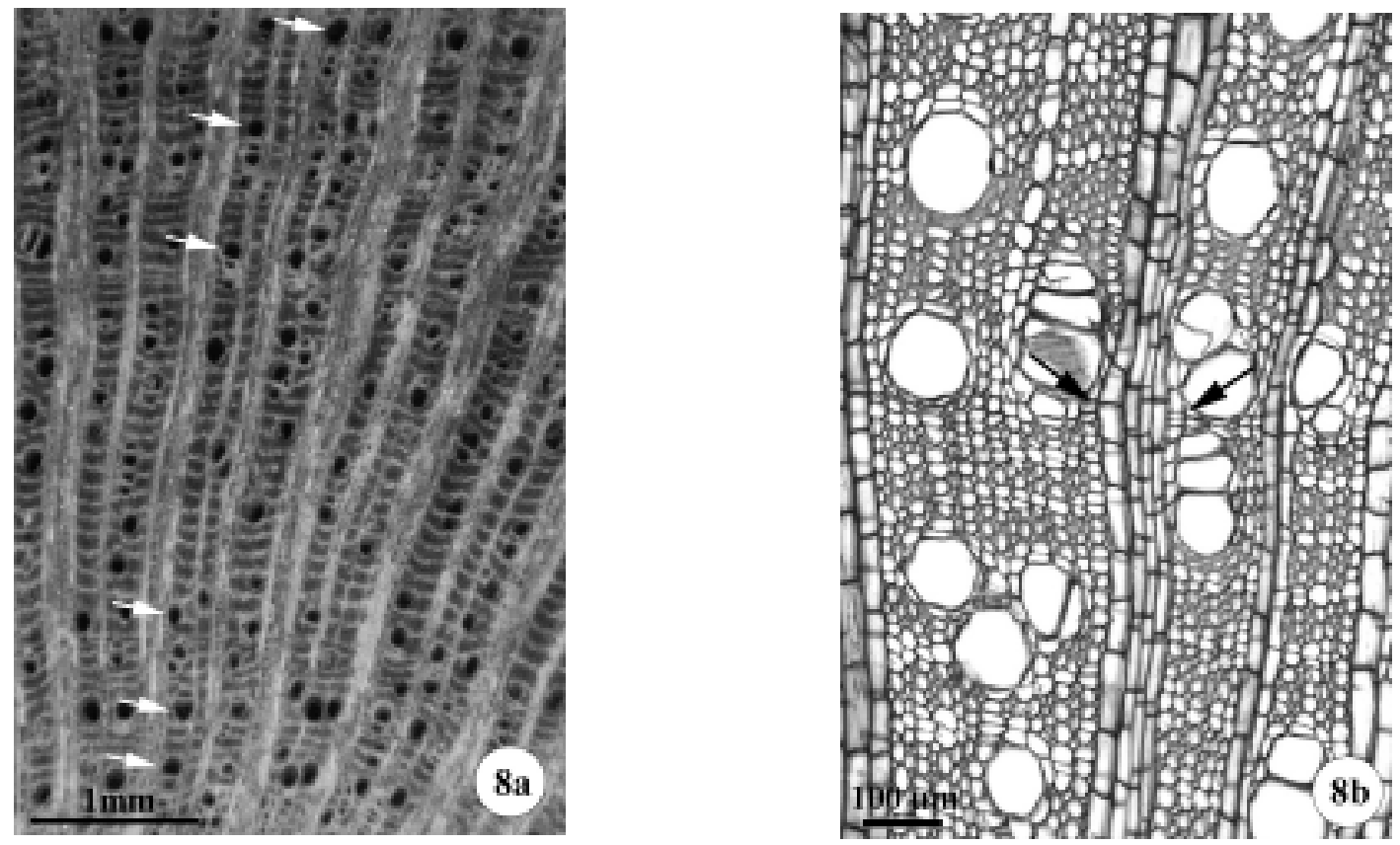

Figure 8. $a-b$. Transverse section of Annona coriacea wood. a) Photomacrograph. The arrows indicate the largest vessels in tangential arrangement in earlywood. Note the closeness of the parenchyma narrow bands just before the largest vessels in each growth layer. $b$ ) Photomicrograph shows distended rays in the boundary of the growth layers (arrows). 
Marcati, C.R.; Oliveira, J.S. and Machado, S.R. - Biota Neotropica, v6 (n3) - bn00206032006
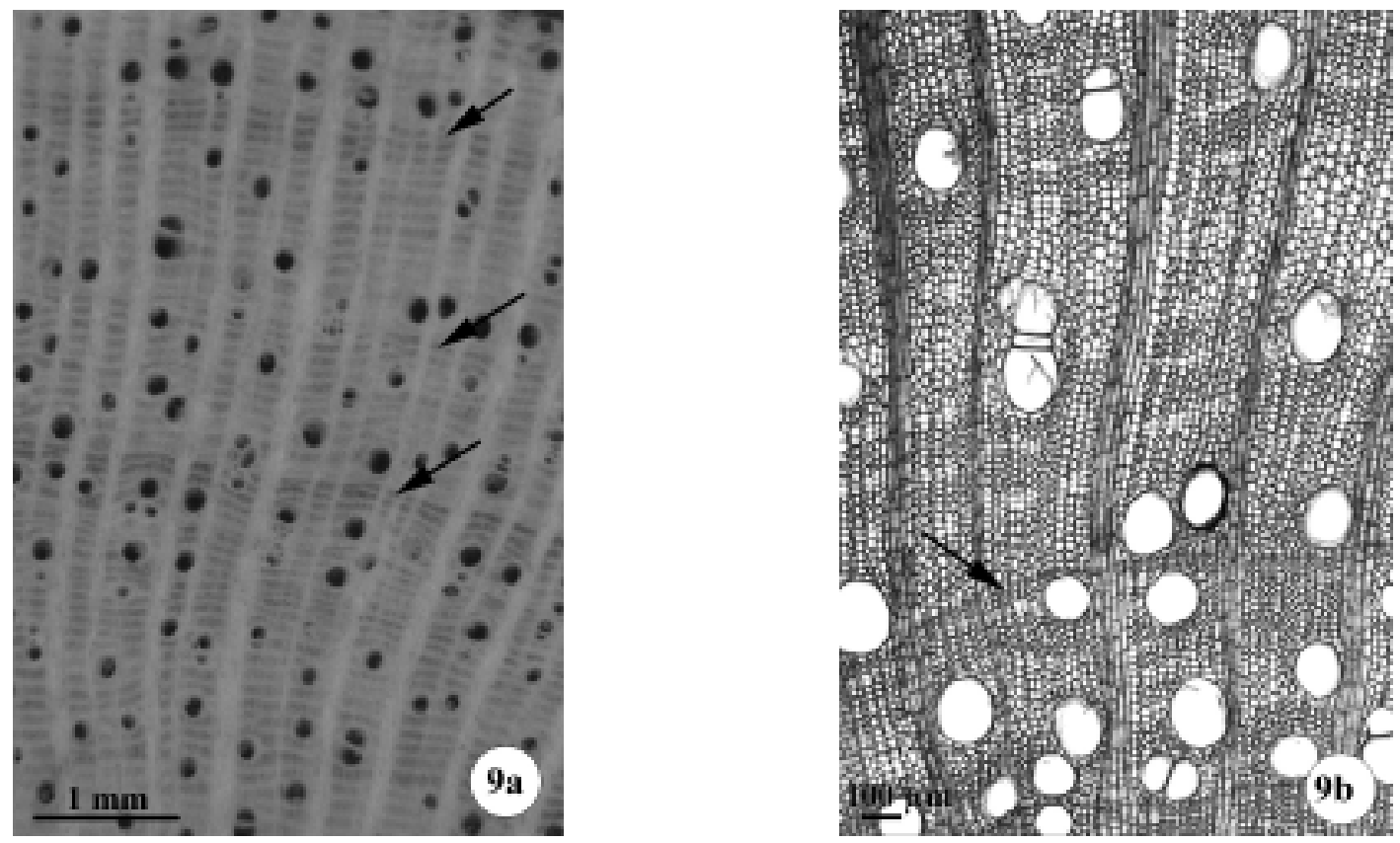

Figure 9. $a-b$. Transverse section of Annona crassiflora wood. a) Photomacrograph. The arrows indicate growth layers boundaries. b) Photomicrograph. Arrow indicates thick-walled latewood fibres in the boundary of the growth layers.
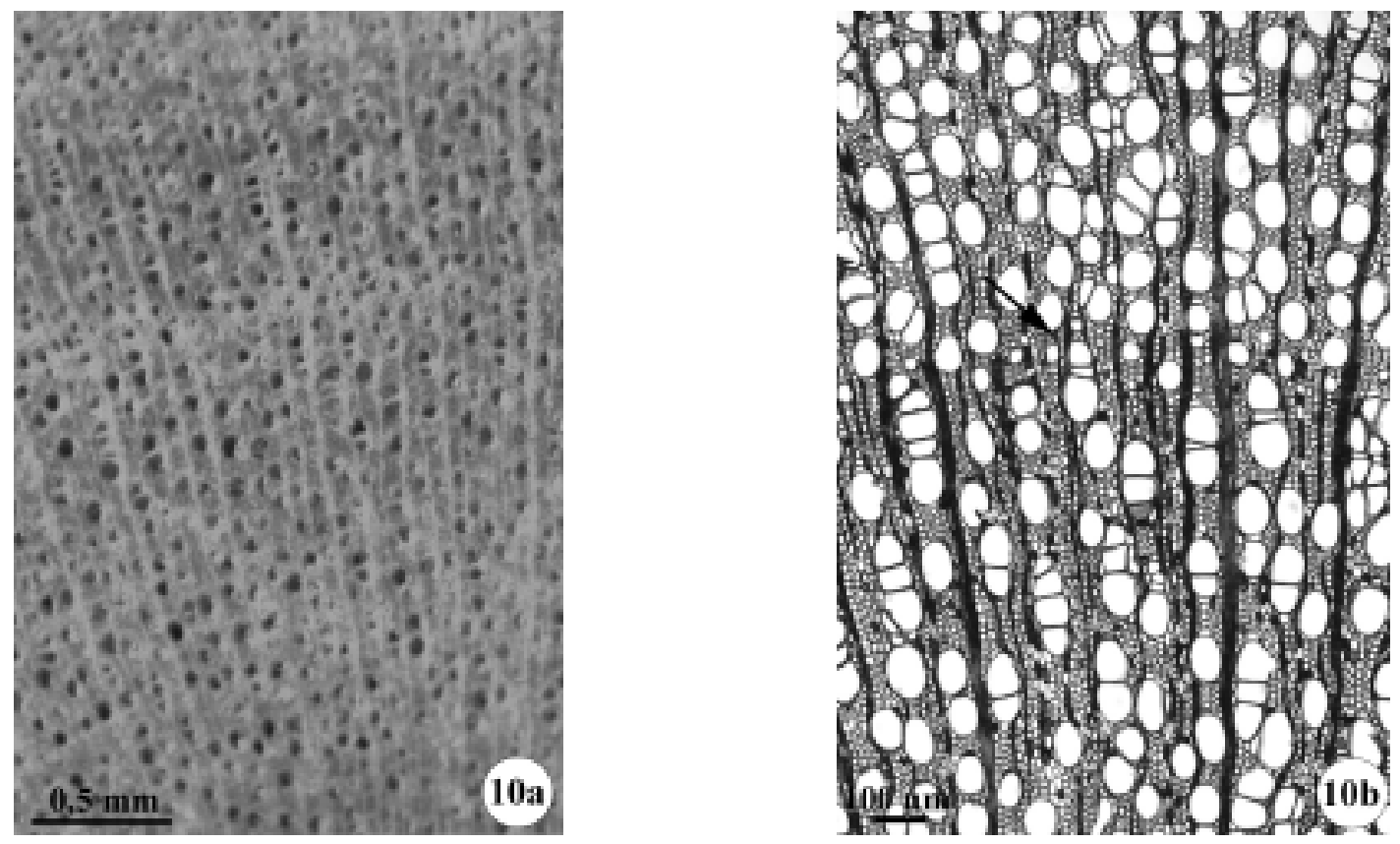

Figure 10. $a-b$. Transverse section of Erythroxylum tortuosum wood. a) Photomacrograph. b) Photomicrograph. Arrow indicates thickwalled and radially flattened latewood fibres and small vessels.

http://www.biotaneotropica.org.br 
Marcati, C.R.; Oliveira, J.S. and Machado, S.R. - Biota Neotropica, v6 (n3) - bn00206032006
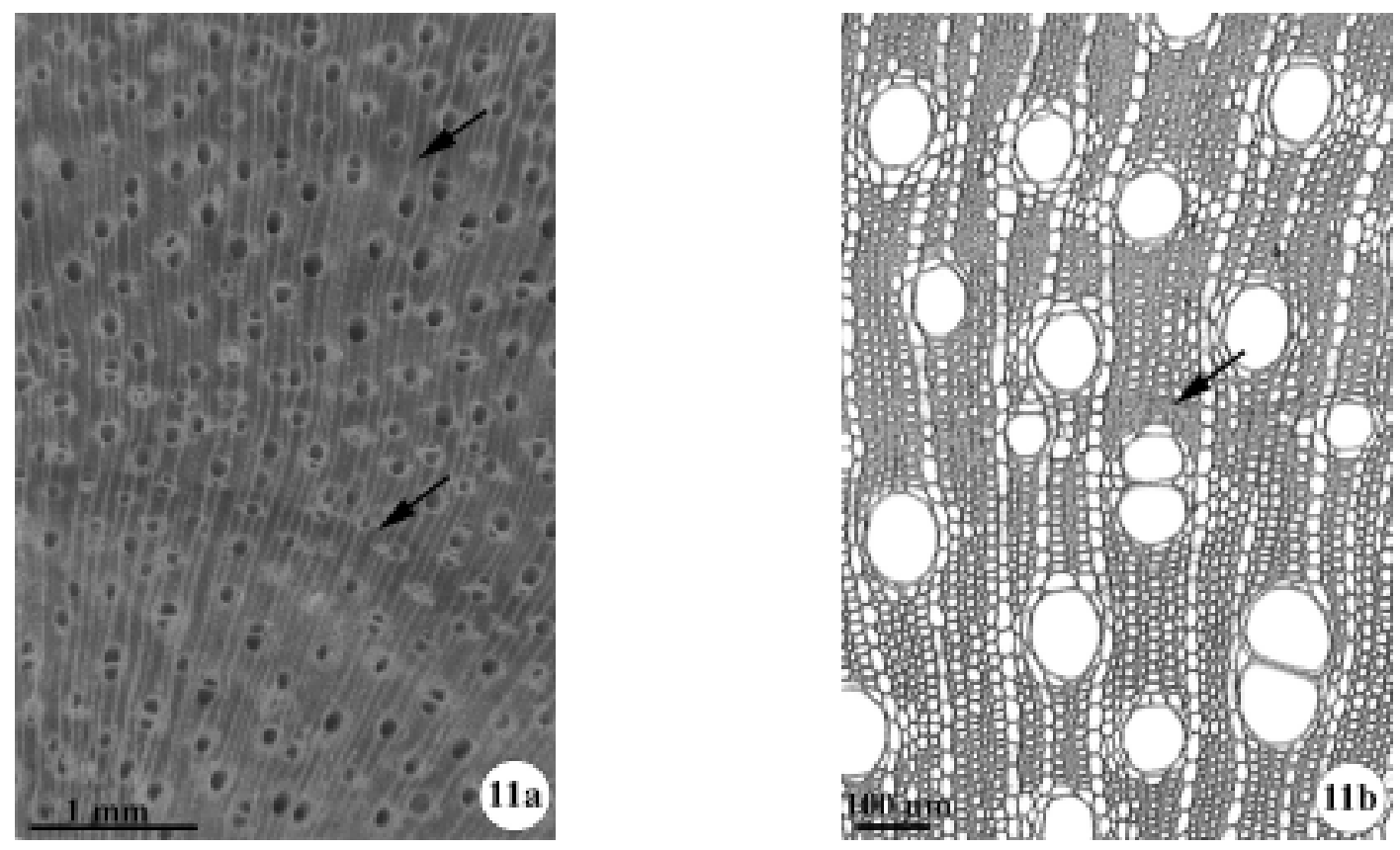

Figure 11. a-b. Transverse section of Terminalia brasiliensis wood. a) Photomacrograph. Arrows indicate growth layers boundaries. b) Photomicrograph. Arrow indicates thick-walled and radially flattened latewood fibres.
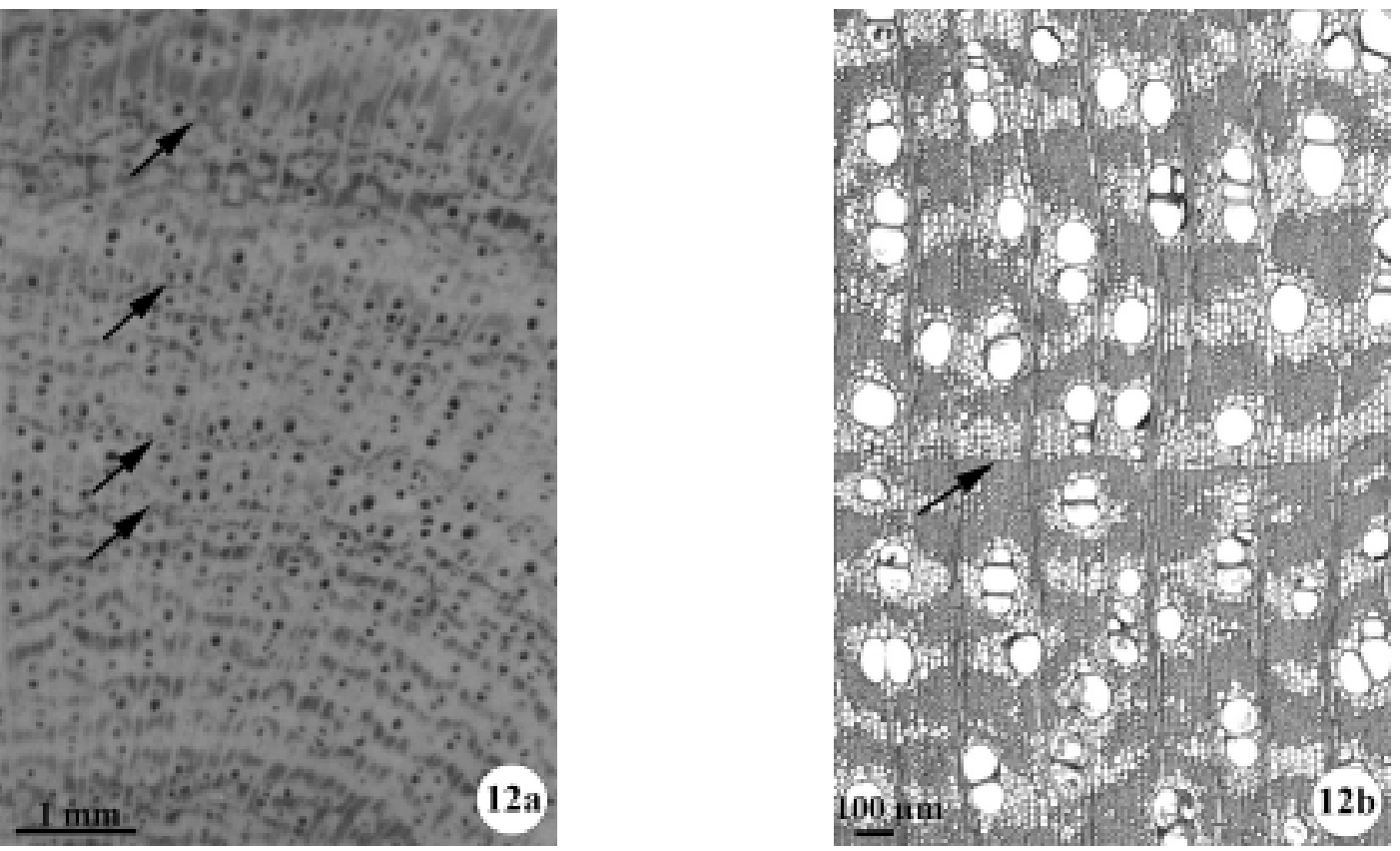

Figure 12. $a-b$. Transverse section of Qualea grandiflora wood. a) Photomacrograph. Arrows indicate marginal lines of axial parenchyma marking growth layers boundaries. b) Photomicrograph. Arrow indicates thick-walled and radially flattened latewood fibres.

http://www.biotaneotropica.org.br 
Marcati, C.R.; Oliveira, J.S. and Machado, S.R. - Biota Neotropica, v6 (n3) - bn00206032006
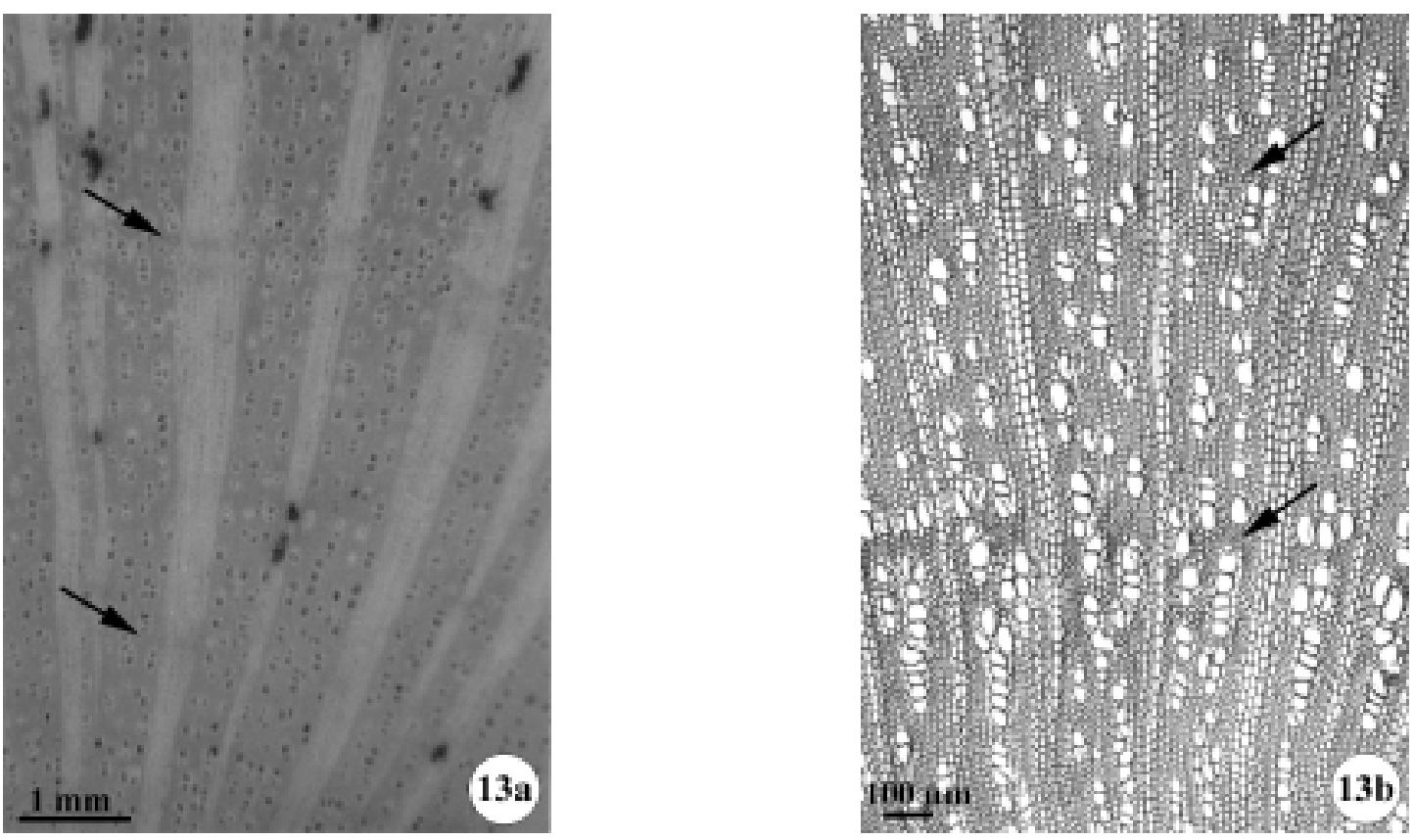

Figure 13. $a-b$. Transverse section of Rapanea umbellata wood. a) Photomacrograph. Arrows indicate growth layers boundaries. b) Photomicrograph. Arrows indicate thick-walled and slight radially flattened latewood fibres.
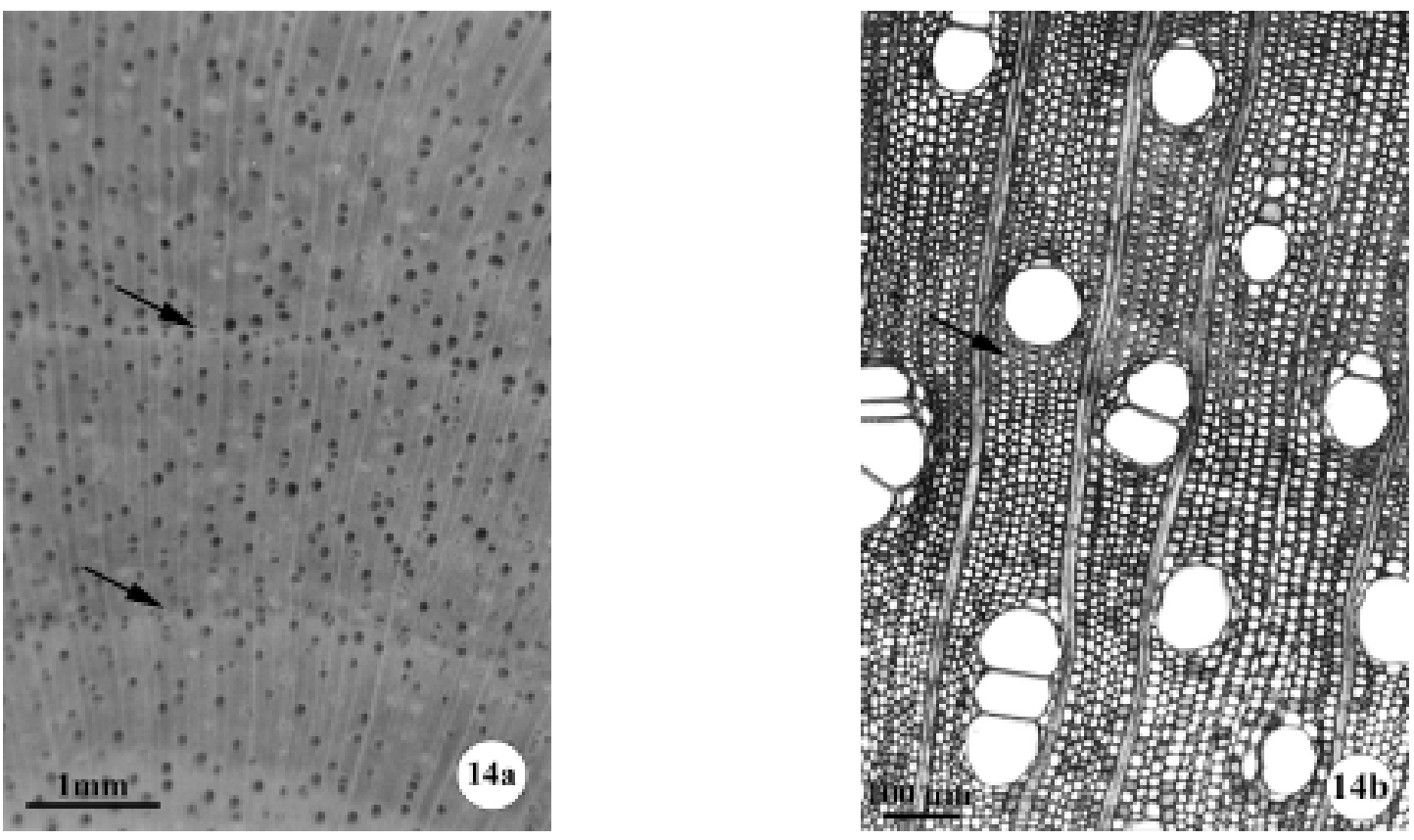

Figure 14. $a-b$. Transverse section of Tapirira guianensis wood. a) Photomacrograph. The arrows indicate growth layers boundaries. $b$ ) Photomicrograph shows thick-walled latewood fibres (arrow).

http://www.biotaneotropica.org.br 
Marcati, C.R.; Oliveira, J.S. and Machado, S.R. - Biota Neotropica, v6 (n3) - bn00206032006
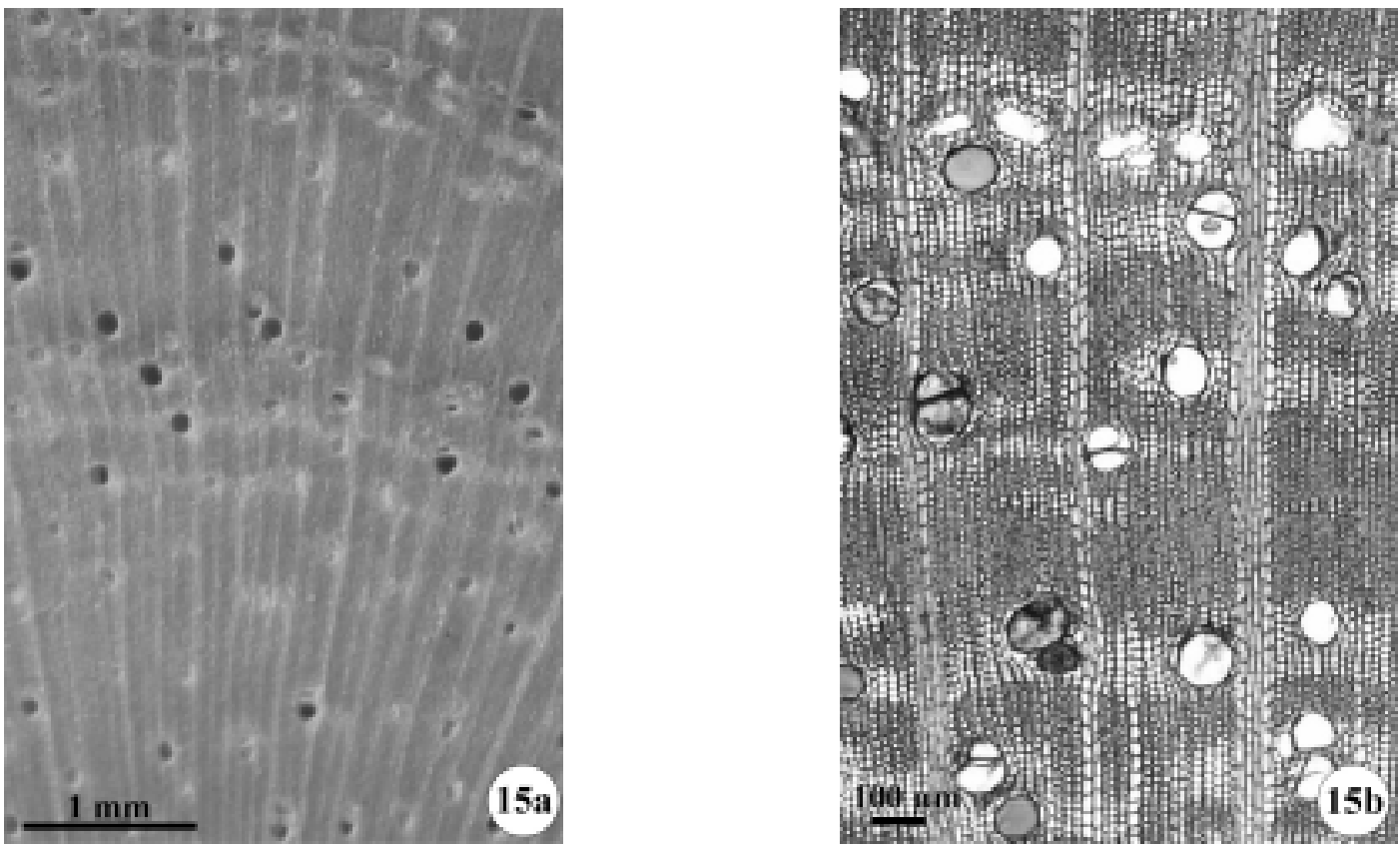

Figure 15. a-b. Transverse section of Vochysia cinnamomea wood. a) Photomacrograph. Note the variation within growth layers in the axial parenchyma distribution. b) Photomicrograph. Note the variation within growth layers in the axial parenchyma distribution and the tangential arrangement of the traumatic canals above in the figure.
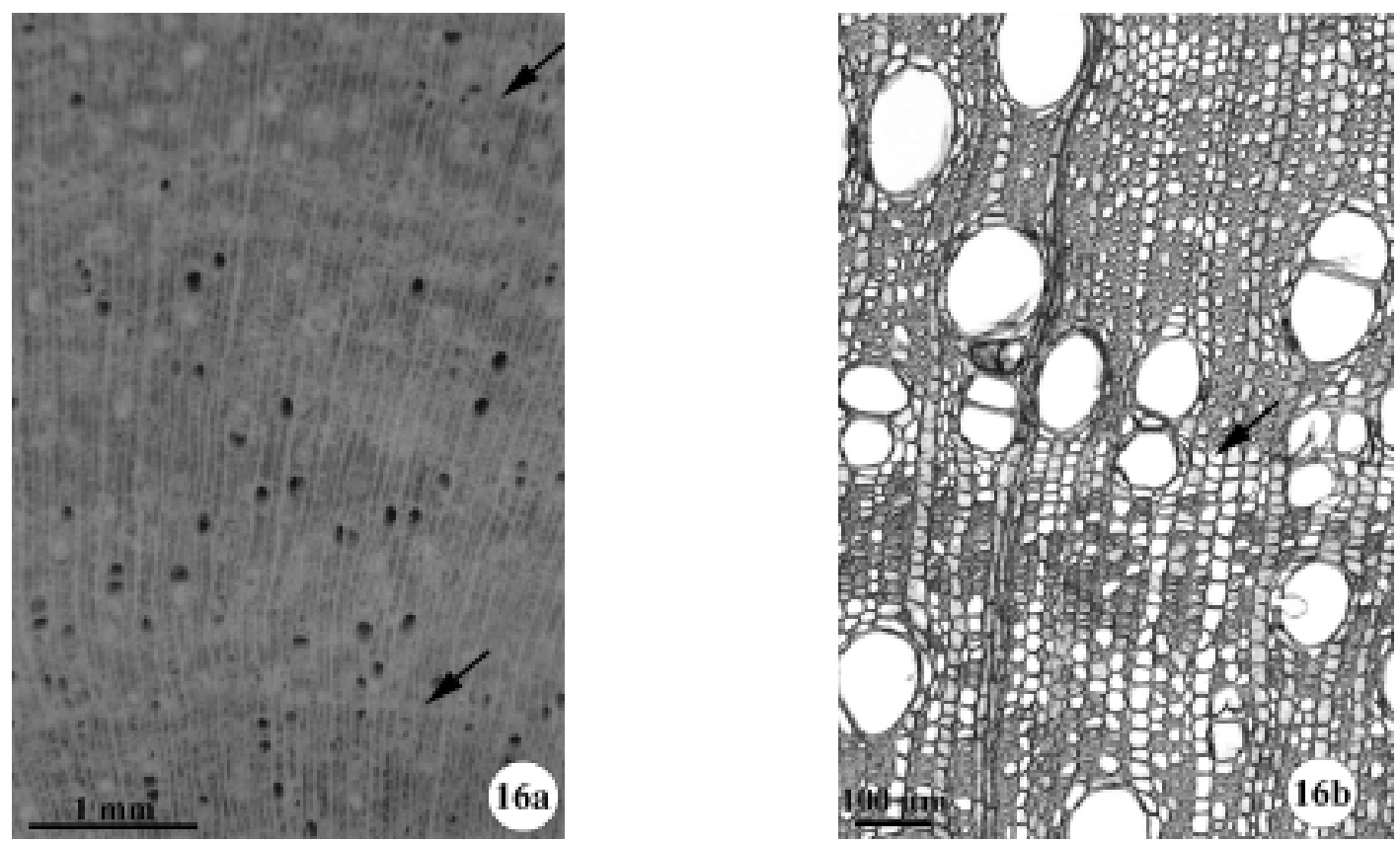

Figure 16. $a-b$. Transverse section of Caryocar brasiliense wood. a) Photomacrograph. Arrows indicate marginal lines of axial parenchyma. b) Photomicrograph. Arrow indicates marginal lines of axial parenchyma. 
Marcati, C.R.; Oliveira, J.S. and Machado, S.R. - Biota Neotropica, v6 (n3) - bn00206032006
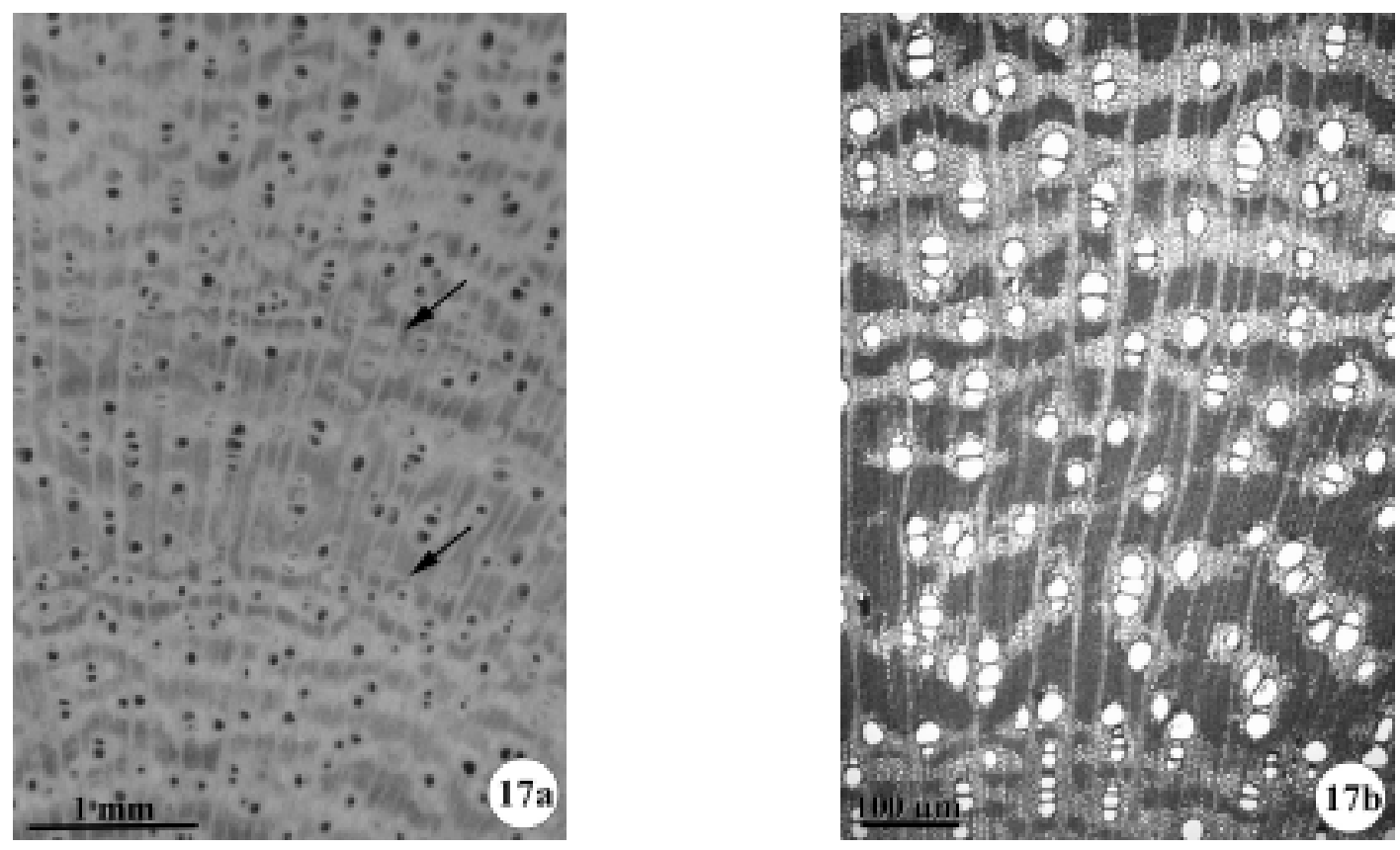

Figure 17. $a-b$. Transverse section of Qualea multiflora wood. a) Photomacrograph. Arrows indicate marginal lines of axial parenchyma. $b$ ) Photomicrograph. Note variation within growth layers in the axial parenchyma distribution.
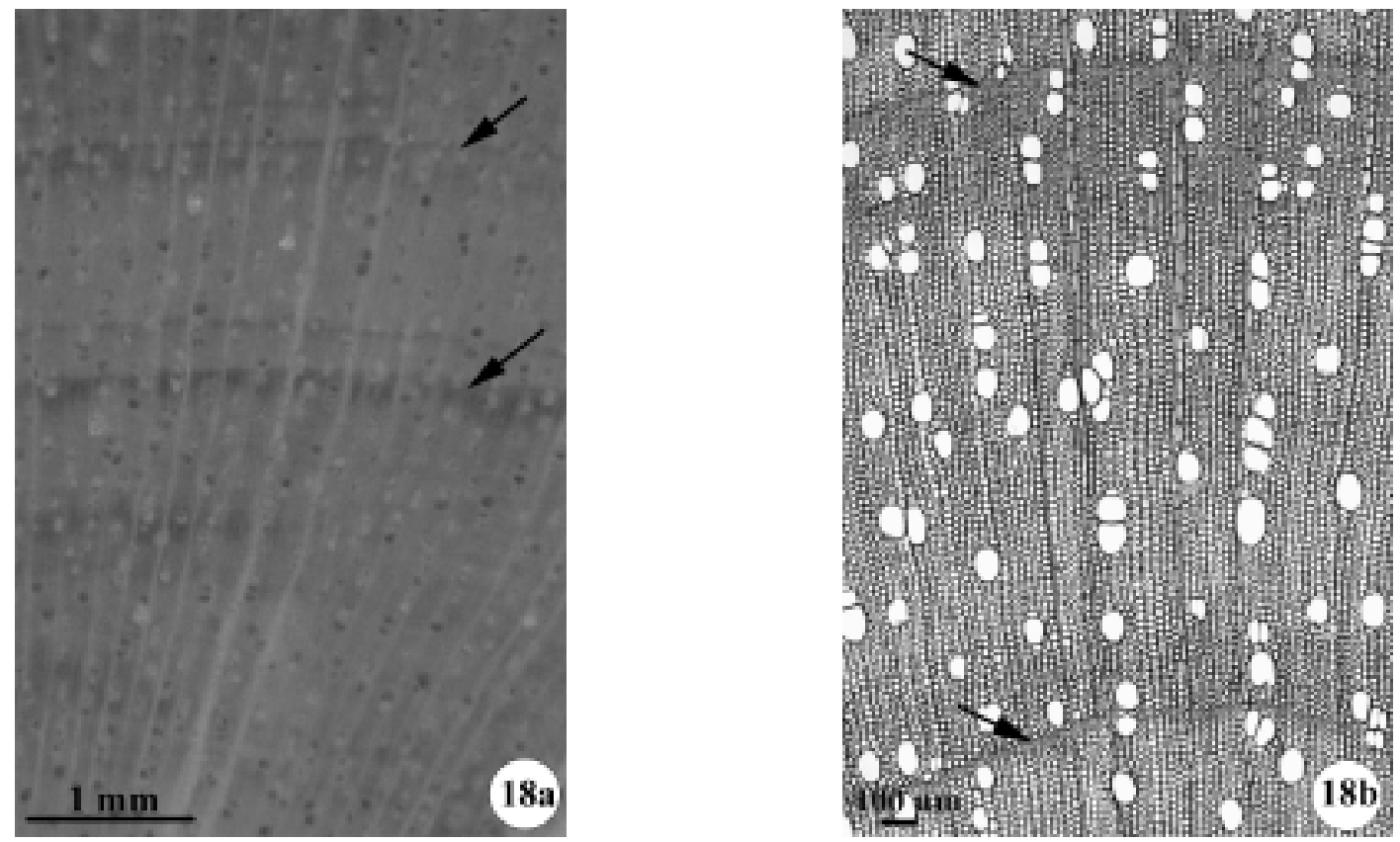

Figure 18. $a-b$. Transverse section of Didymopanax vinosum wood. a) Photomacrograph. Arrows indicate fibre zones. b) Photomicrograph. Thick-walled and radially flattened latewood fibres in fibre zones (arrows). 
Marcati, C.R.; Oliveira, J.S. and Machado, S.R. - Biota Neotropica, v6 (n3) - bn00206032006
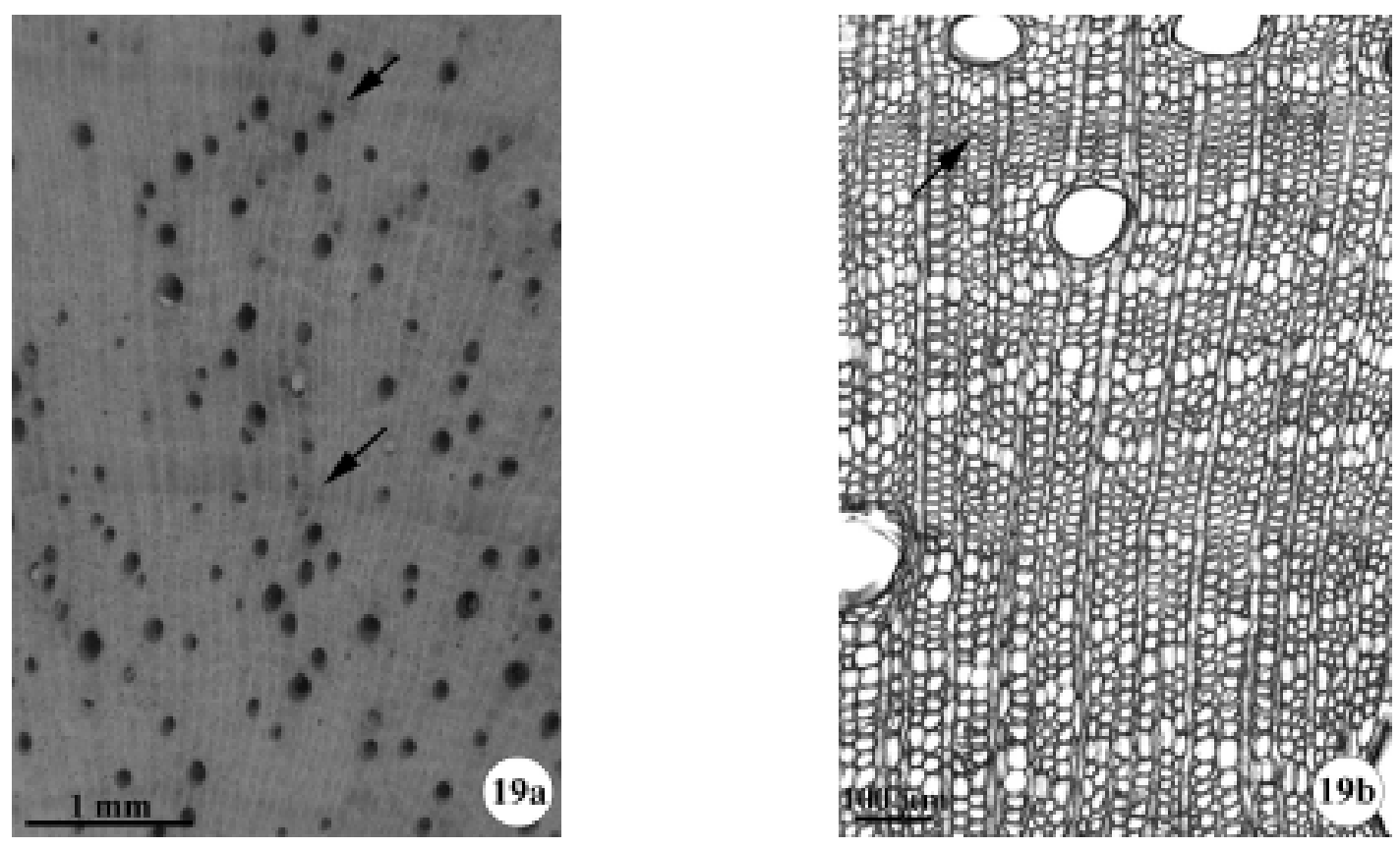

Figure 19. $a-b$. Transverse section of Couepia grandiflora wood. a) Photomacrograph. Arrows indicate fibre zones. b) Photomicrograph. Arrow indicates thick-walled and radially flattened latewood fibres in fibre zones.
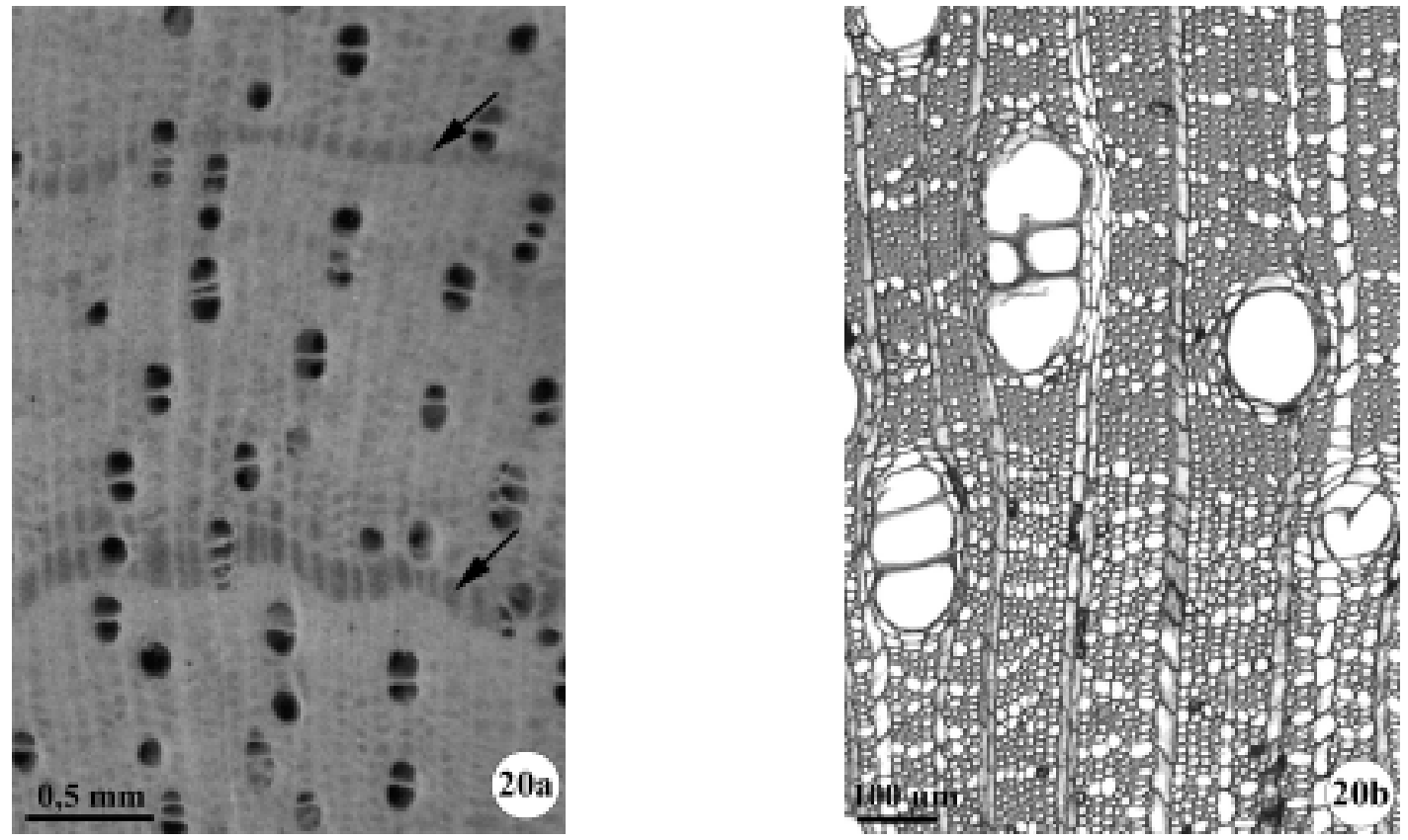

Figure 20. $a-b$. Transverse section of Diospyrus hispida wood. a) Photomacrograph. Arrows indicate fibre zones. b) Photomicrograph. Note that the narrow bands of axial parenchyma tend to come closer towards the end of the growth ring.

http://www.biotaneotropica.org.br 
Marcati, C.R.; Oliveira, J.S. and Machado, S.R. - Biota Neotropica, v6 (n3) - bn00206032006
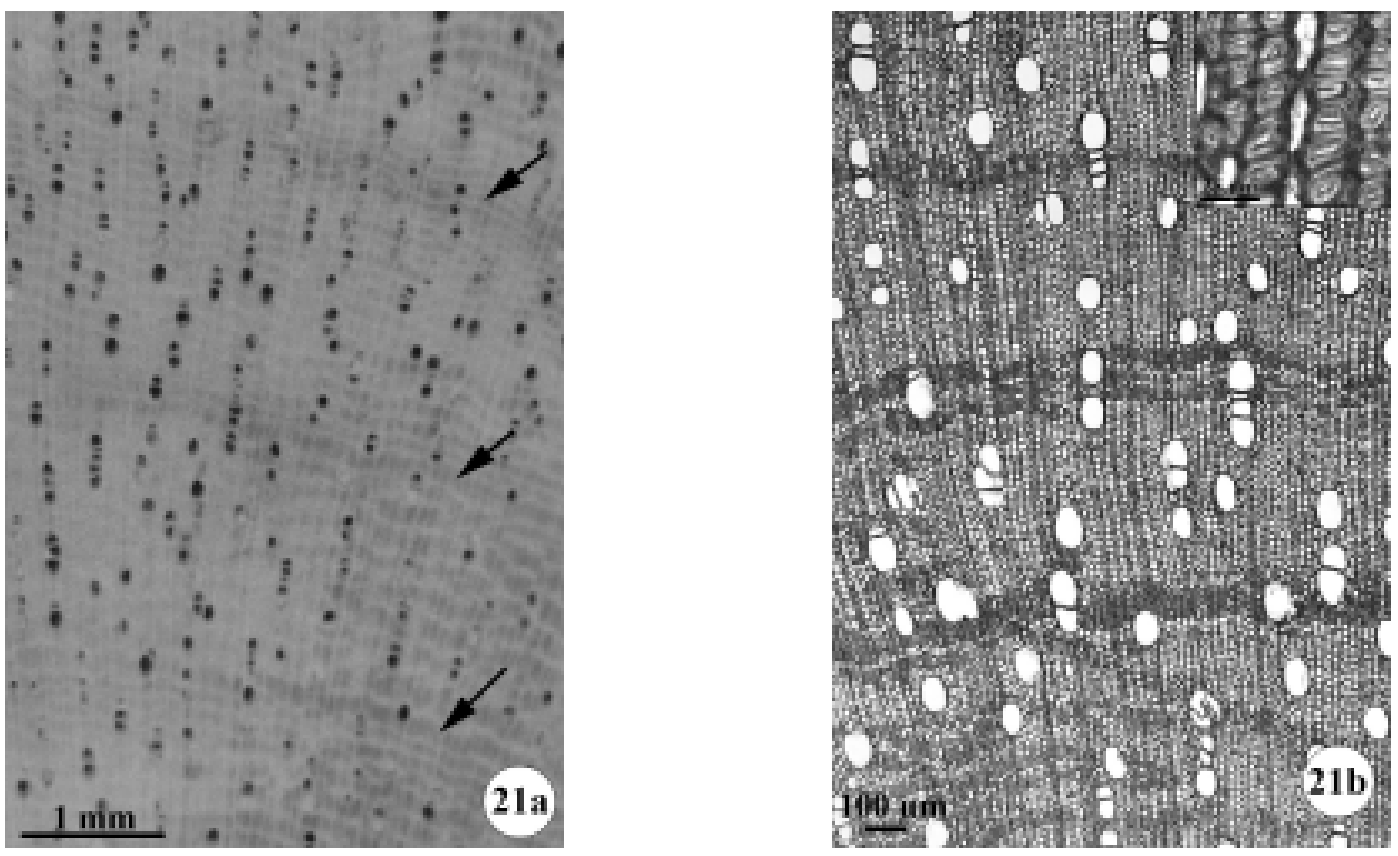

Figure 21. a-b. Transverse section of Pera glabrata wood. a) Photomacrograph. Arrows indicate fibre zones. b) Photomicrograph. Note irregular zones of gelatinous fibres adjacent to the growth layers. Gelatinous fibres in detail.
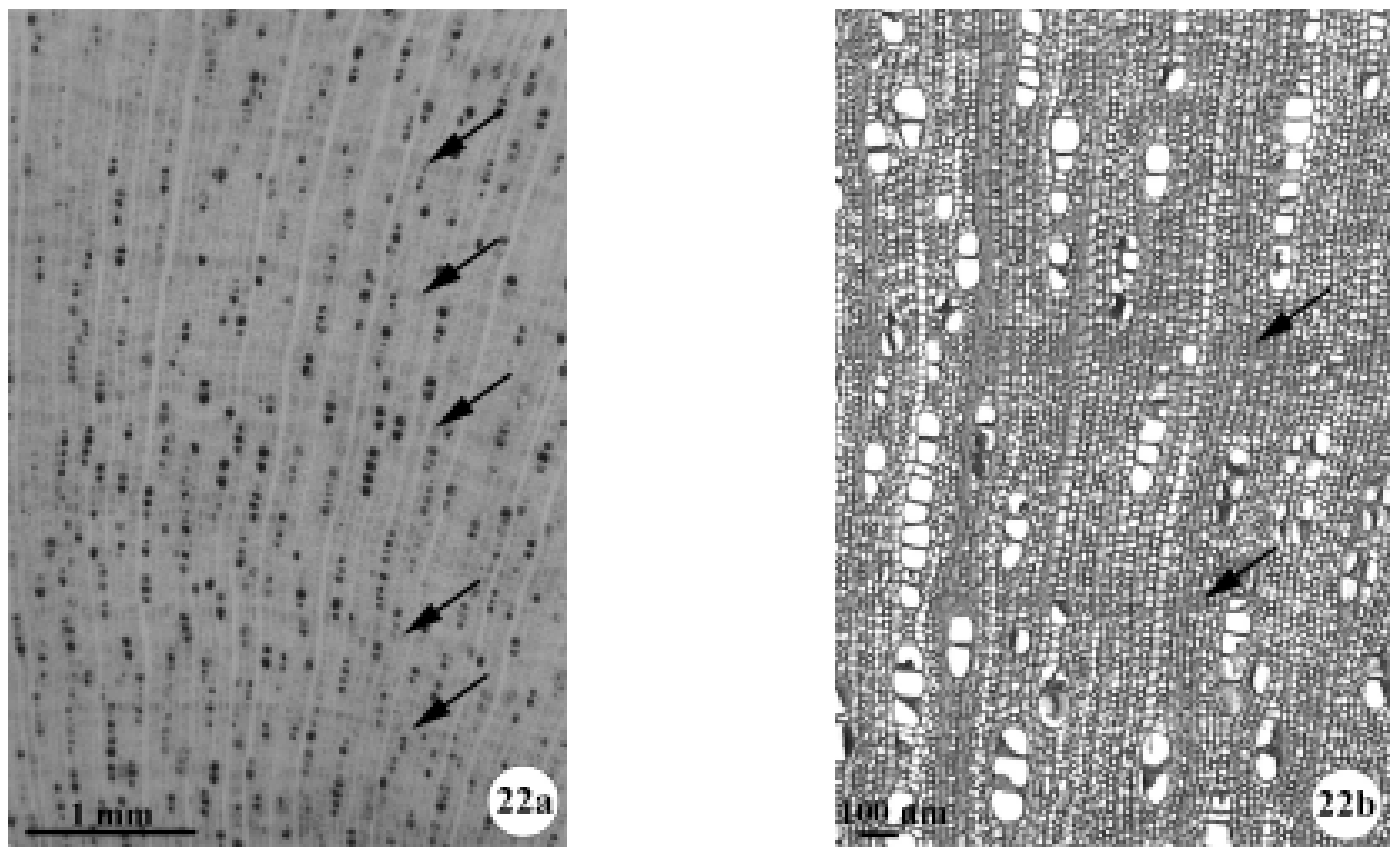

Figure 22. $a$-b. Transverse section of Styrax ferrugineus wood. a) Photomacrograph. Arrows indicate fibre zones. b) Photomicrograph. Arrows indicate thick-walled latewood fibres in fibre zones.

http://www.biotaneotropica.org.br 

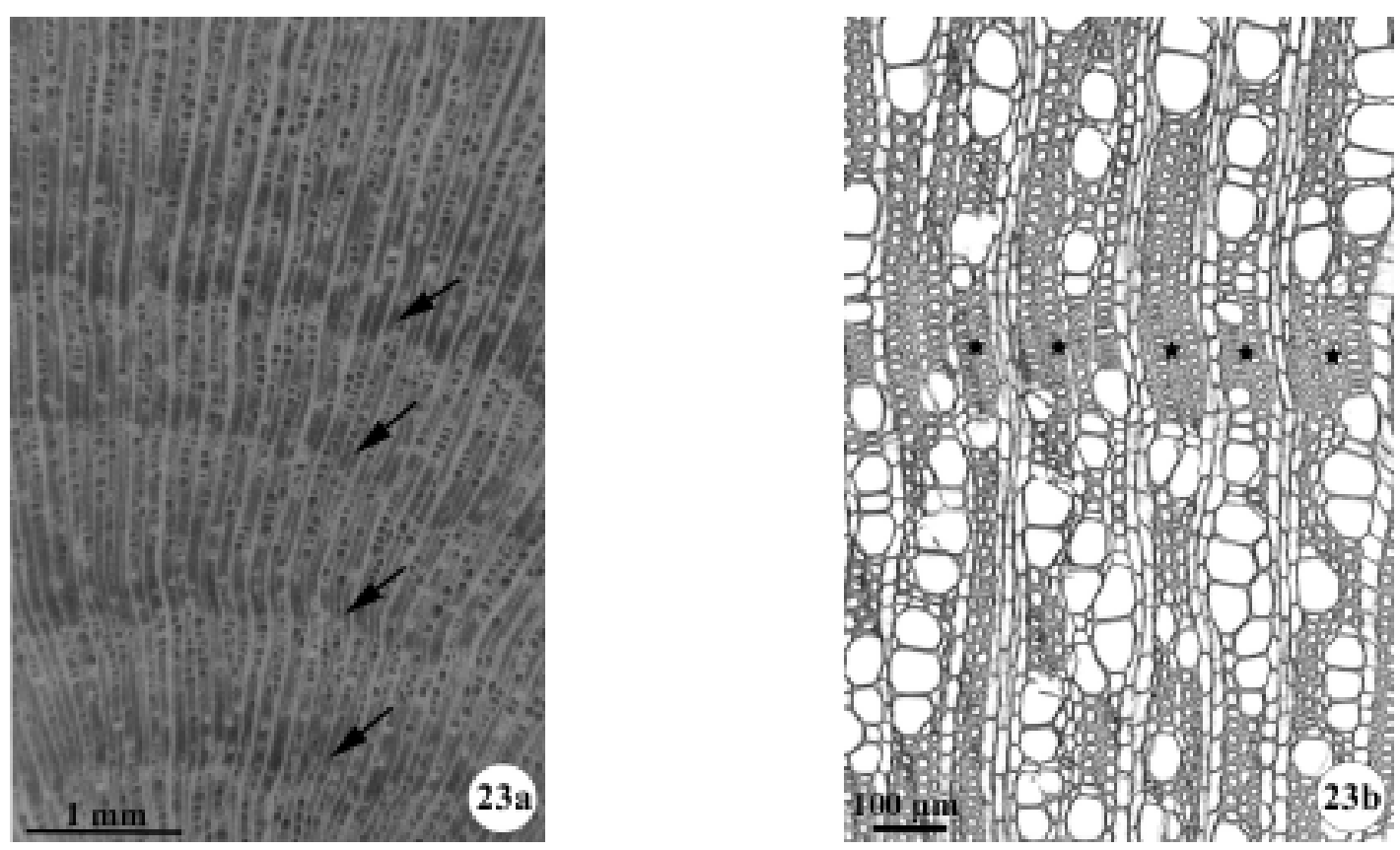

Figure 23. $a-b$. Transverse section of Byrsonima coccolobifolia wood. a) Photomacrograph. Arrows indicate fibre zones. b) Photomicrograph. Small stars indicate thick-walled and radially flattened latewood fibres in fibre zone. Note that the rays become narrow in this region.
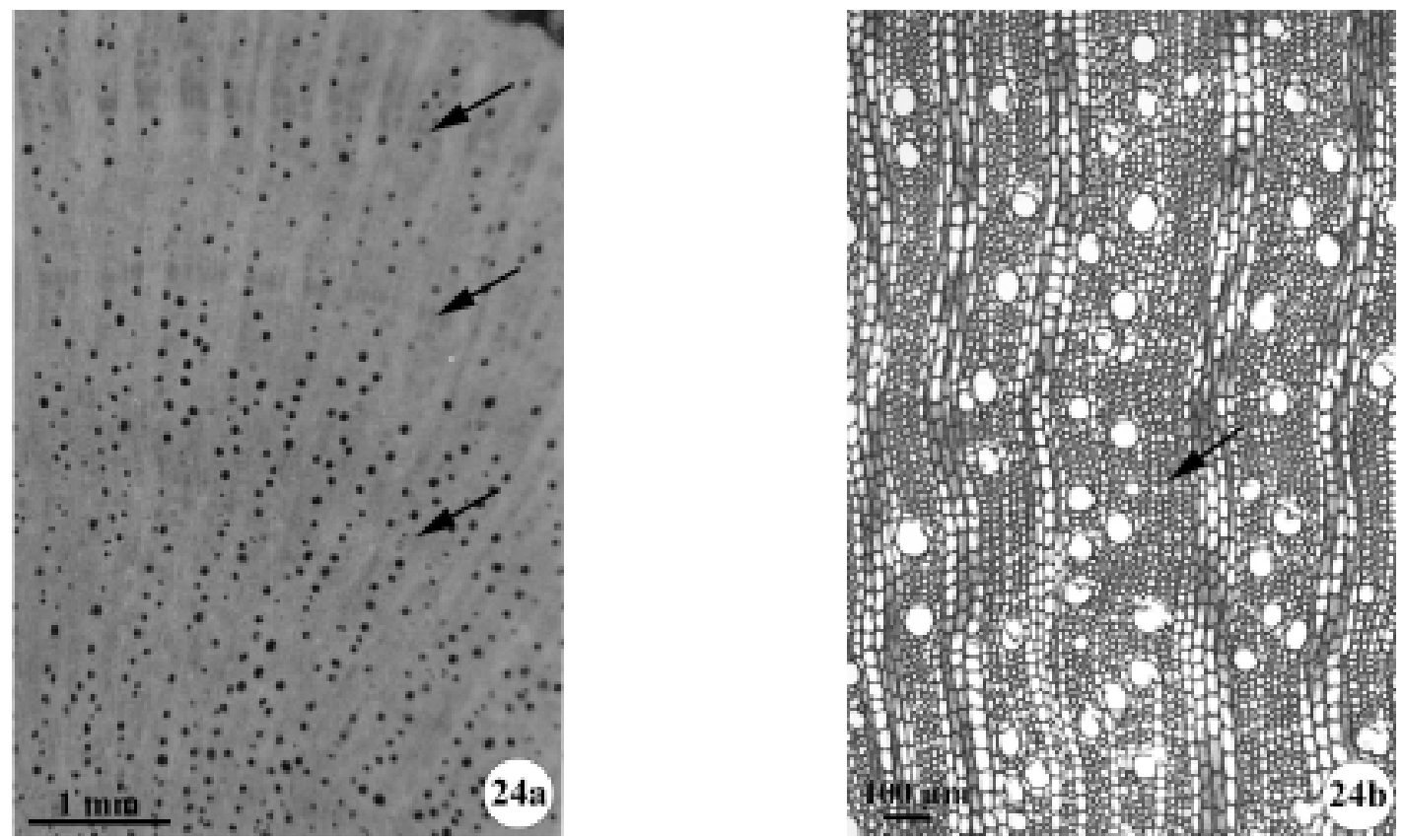

Figure 24. a-b. Transverse section of Ouratea spectabilis wood. a) Photomacrograph. Arrows indicate fibre zones. b) Photomicrograph. Arrow indicates thick-walled and radially flattened latewood fibres in fibre zone.

http://www.biotaneotropica.org.br 
Marcati, C.R.; Oliveira, J.S. and Machado, S.R. - Biota Neotropica, v6 (n3) - bn00206032006
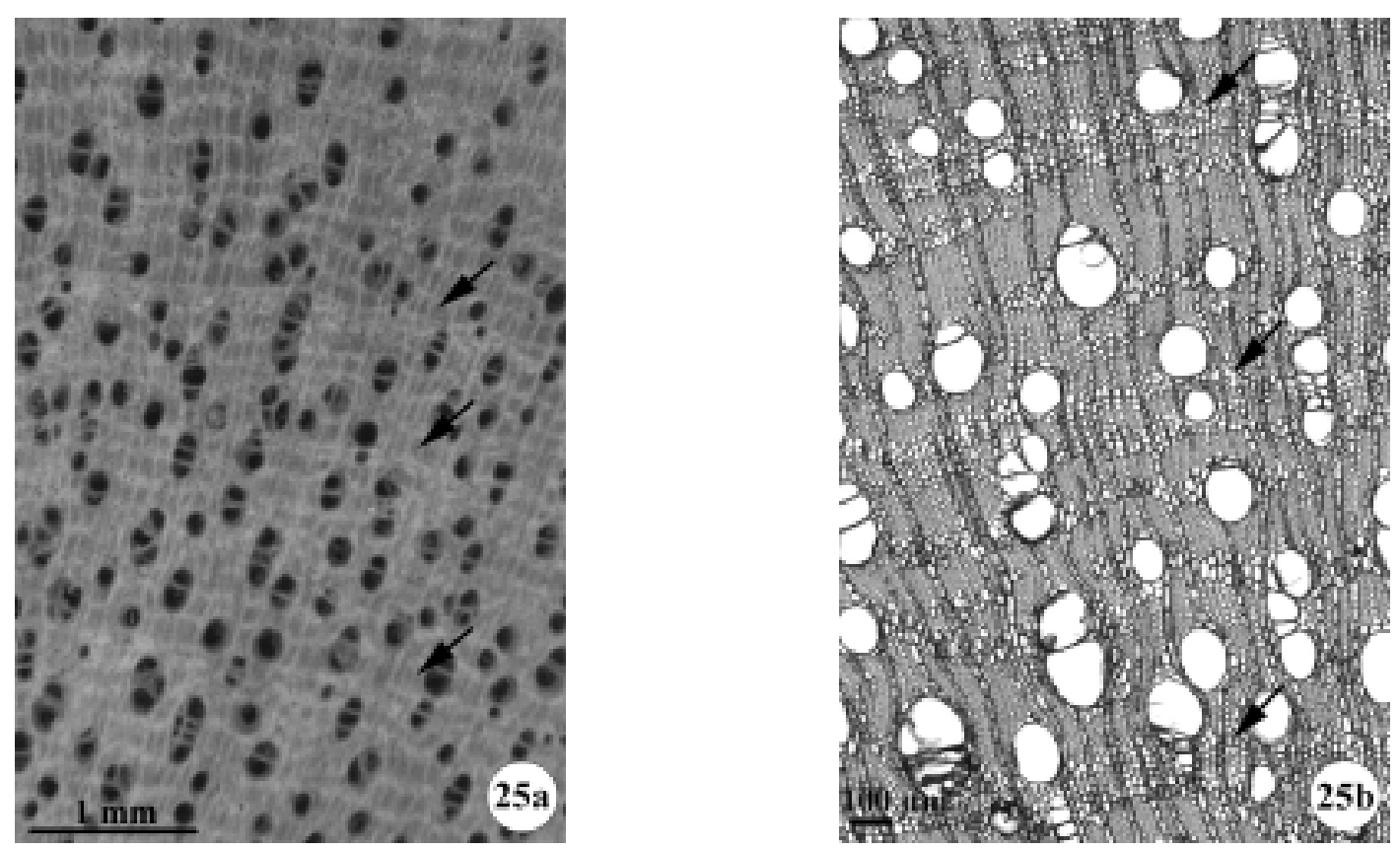

Figure 25. $a$-b. Transverse section of Kielmeyera rubriflora wood. a) Photomacrograph. Arrows indicate fibre zones. b) Photomicrograph. Arrows indicate straight lines of marginal parenchyma.
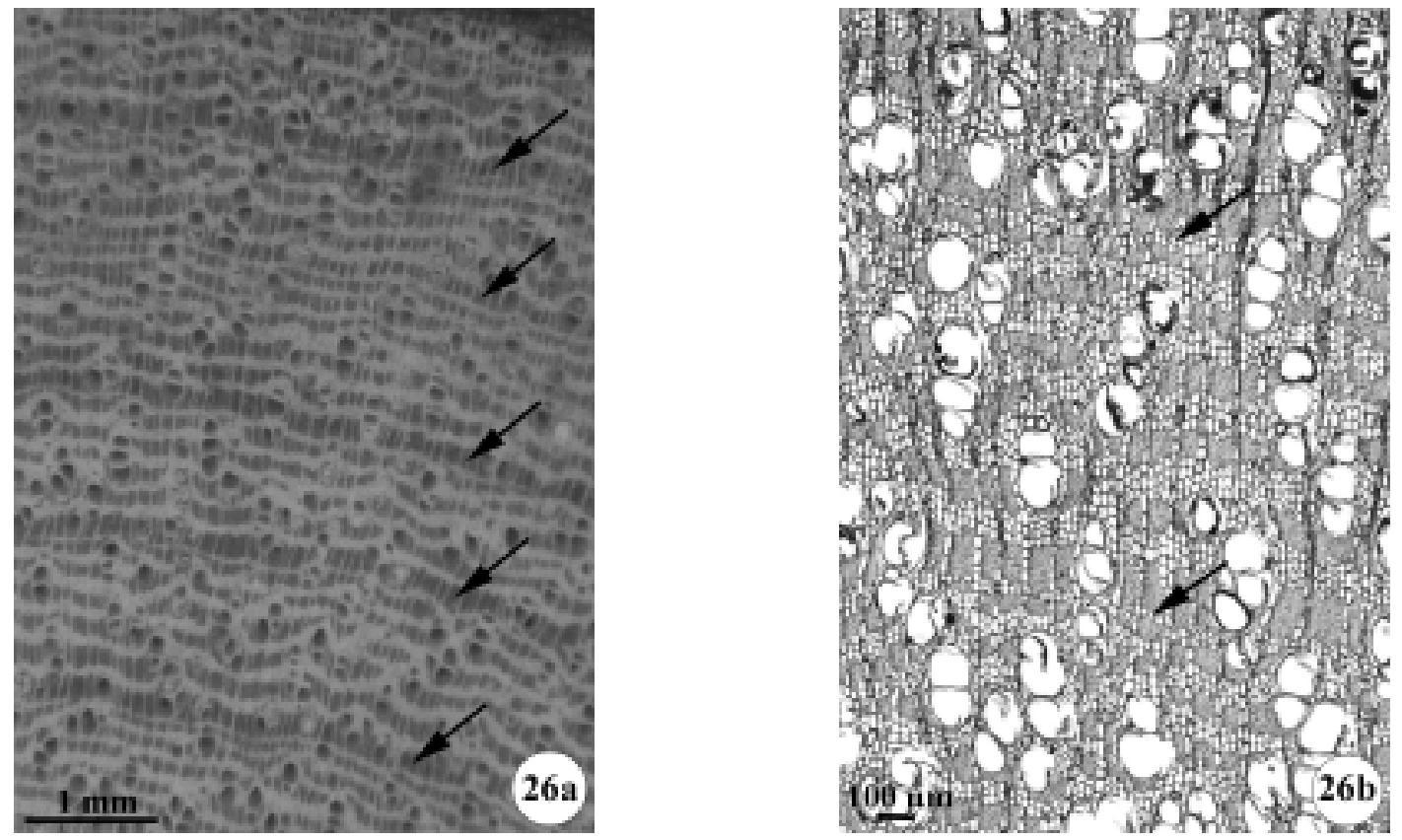

Figure 26. a-b. Transverse section of Pouteria torta wood. a) Photomacrograph. Arrows indicate fibre zones. b) Photomicrograph. Arrows indicate straighter and thinner lines of marginal parenchyma.

http://www.biotaneotropica.org.br 

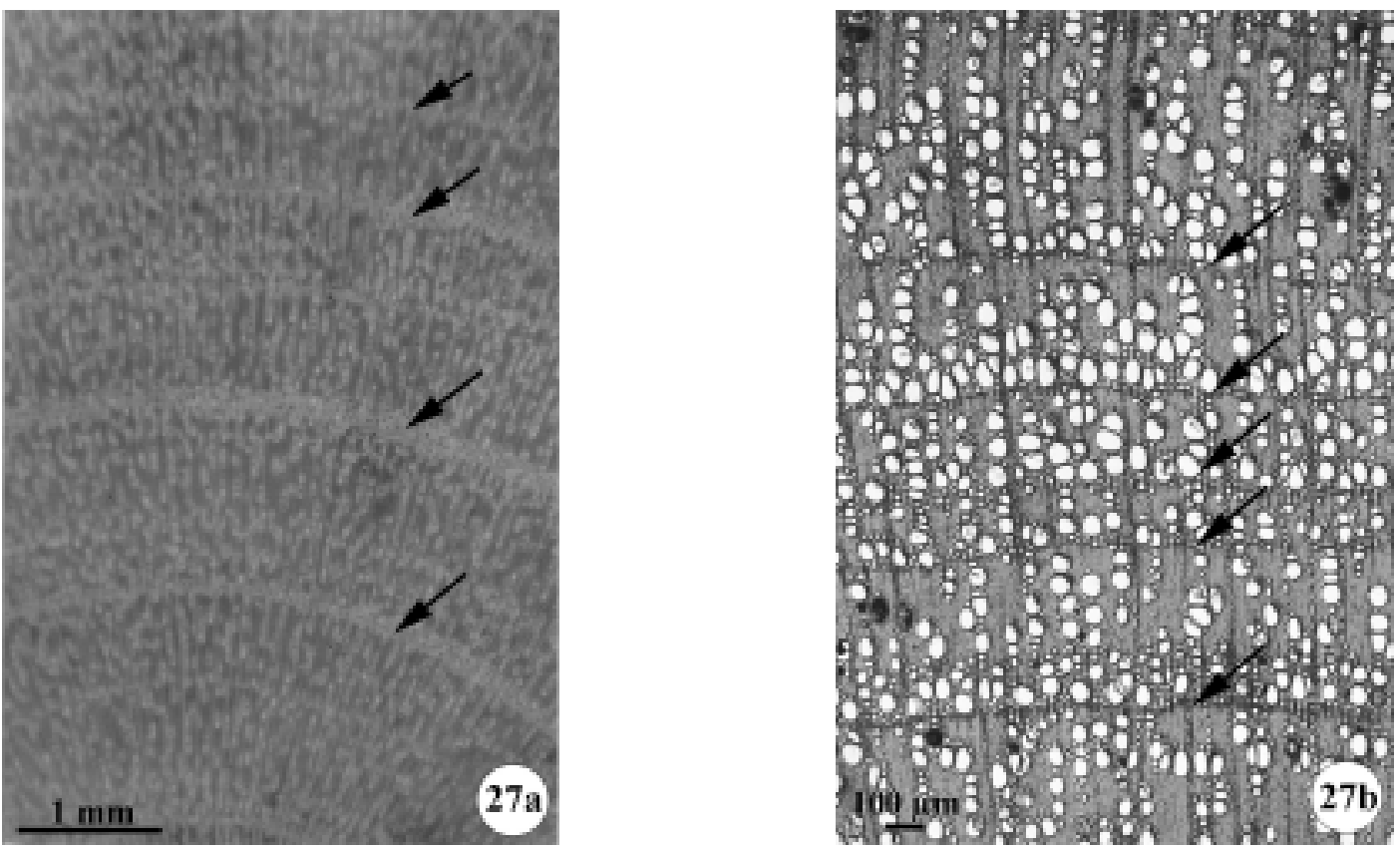

Figure 27. $a-b$. Transverse section of Gochnatia barrosii wood. a) Photomacrograph. Arrows indicate marginal bands of axial parenchyma. b) Photomicrograph. Arrows indicate marginal bands of axial parenchyma. Note higher frequency of vessels in earlywood.
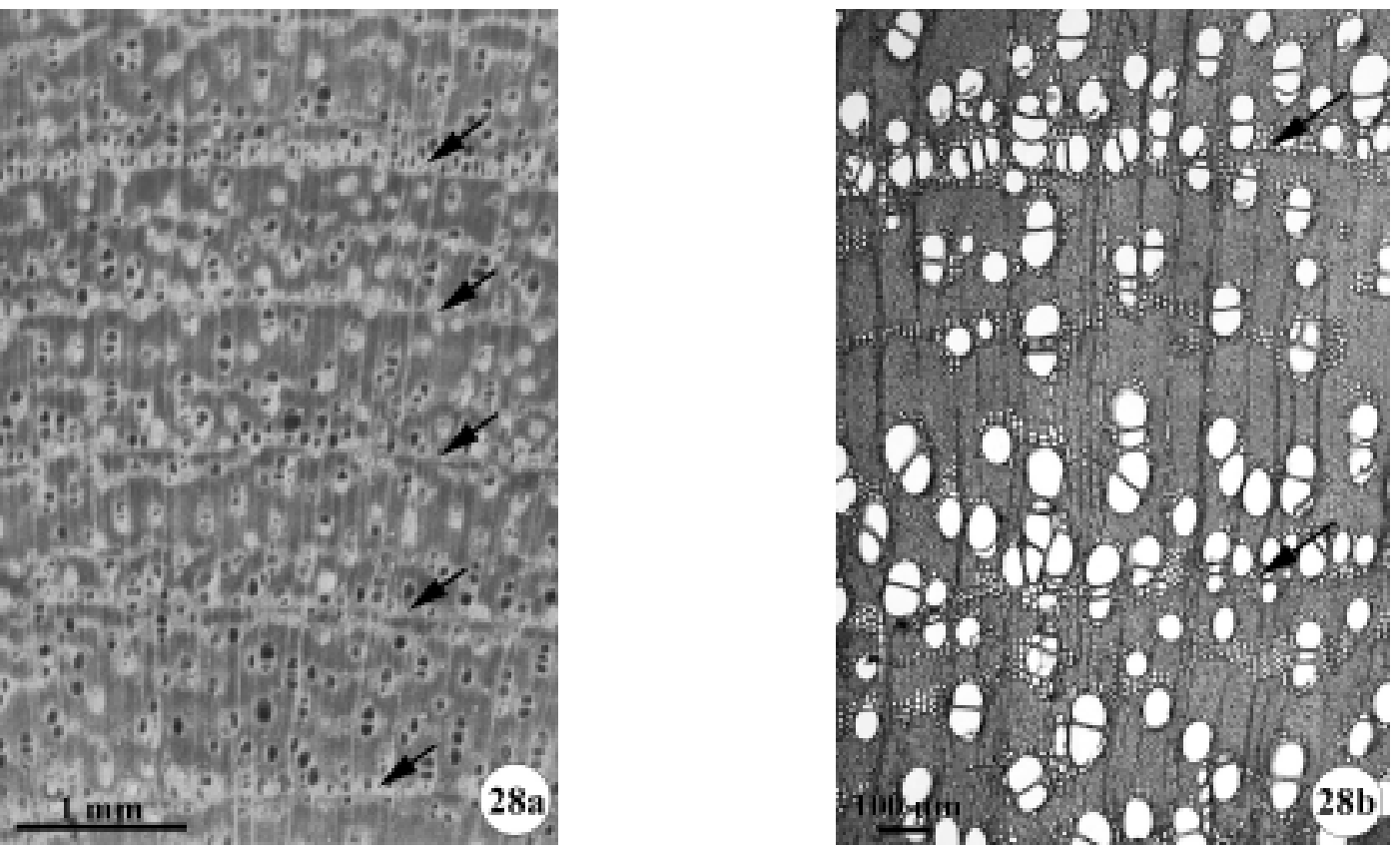

Figure 28. $a-b$ ) Transverse section of Bauhinia rufa wood. a) Photomacrograph. Arrows indicate marginal bands of axial parenchyma. b) Photomicrograph. Arrows indicate marginal bands of axial parenchyma. Note higher frequency of vessels adjacent to the marginal bands.

http://www.biotaneotropica.org.br 
Marcati, C.R.; Oliveira, J.S. and Machado, S.R. - Biota Neotropica, v6 (n3) - bn00206032006
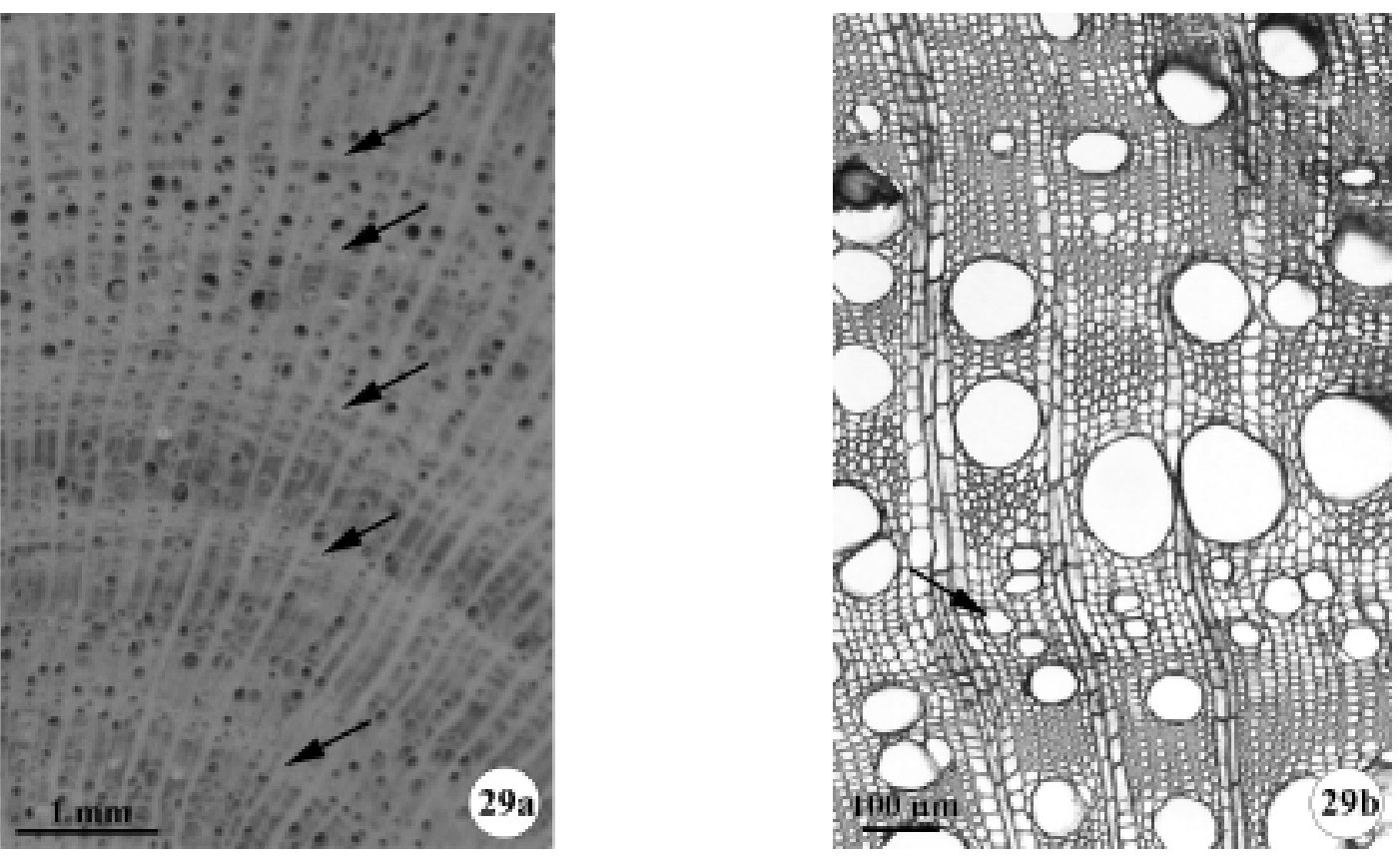

Figure 29. $a-b$. Transverse section of Cordia sellowiana wood. a) Photomacrograph. Arrows indicate marginal bands of parenchyma. $b$ ) Photomicrograph. Arrow indicates small latewood vessels absorbed in marginal parenchyma.
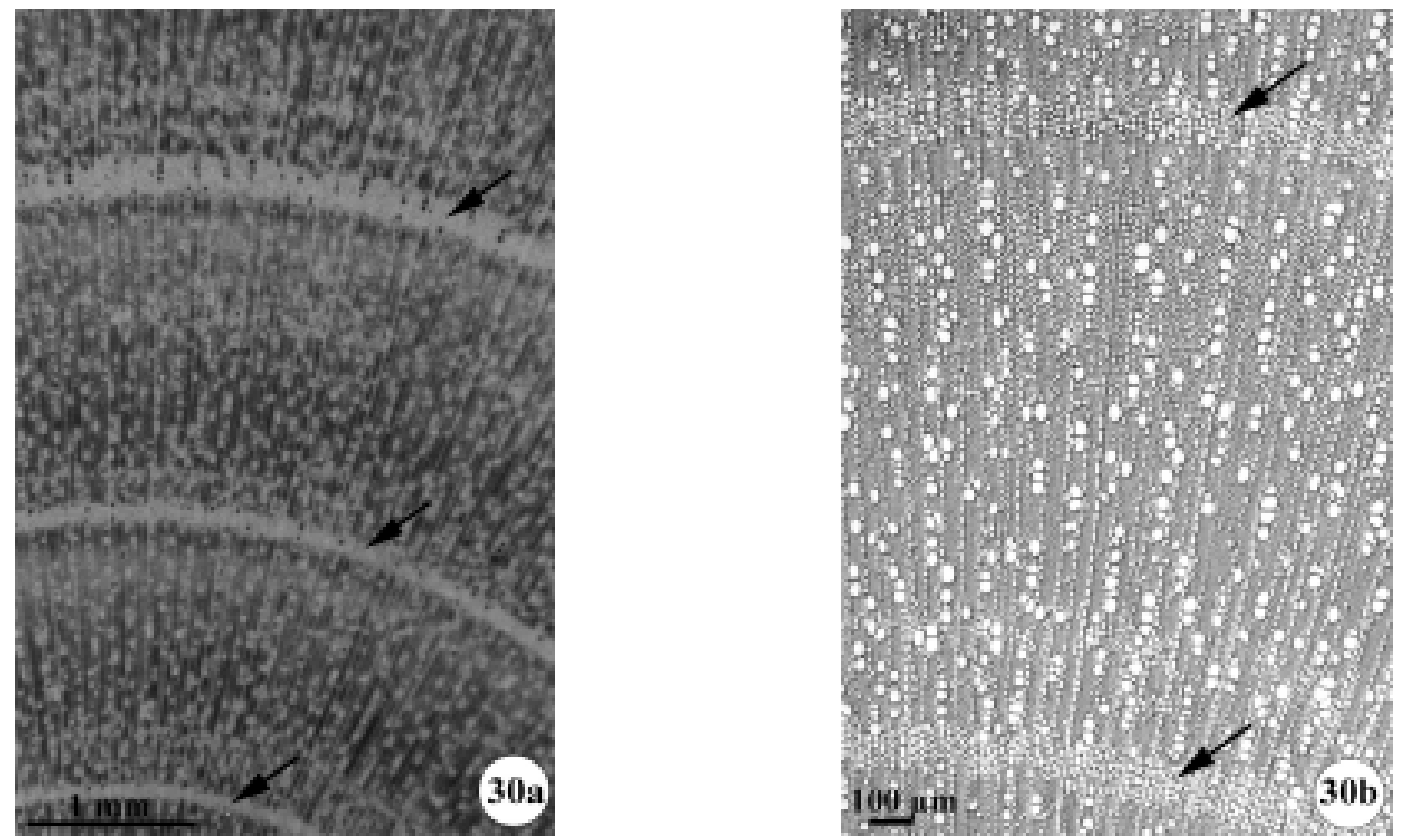

Figure 30. a-b. Transverse section of Alibertia concolor wood. a) Photomacrograph. Arrows indicate marginal bands of axial parenchyma. b. Photomicrograph. Arrows indicate marginal bands. 
Marcati, C.R.; Oliveira, J.S. and Machado, S.R. - Biota Neotropica, v6 (n3) - bn00206032006
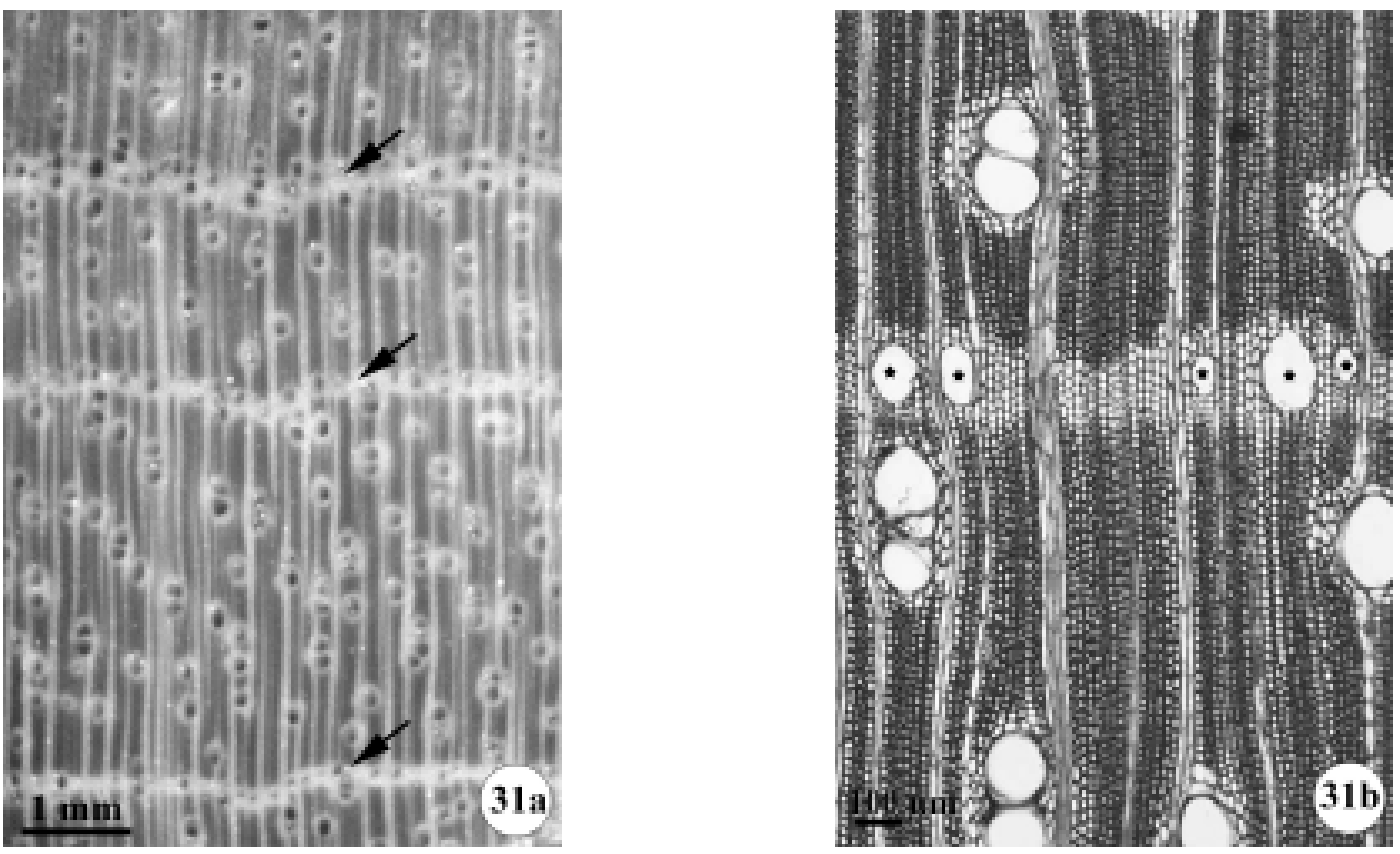

Figure 31. $a-b$. Transverse section of Copaifera langsdorffii wood. a) Photomacrograph. Arrows indicate marginal bands of axial parenchyma. b) Photomicrograph. Small stars indicate axial canals in marginal bands of axial parenchyma.
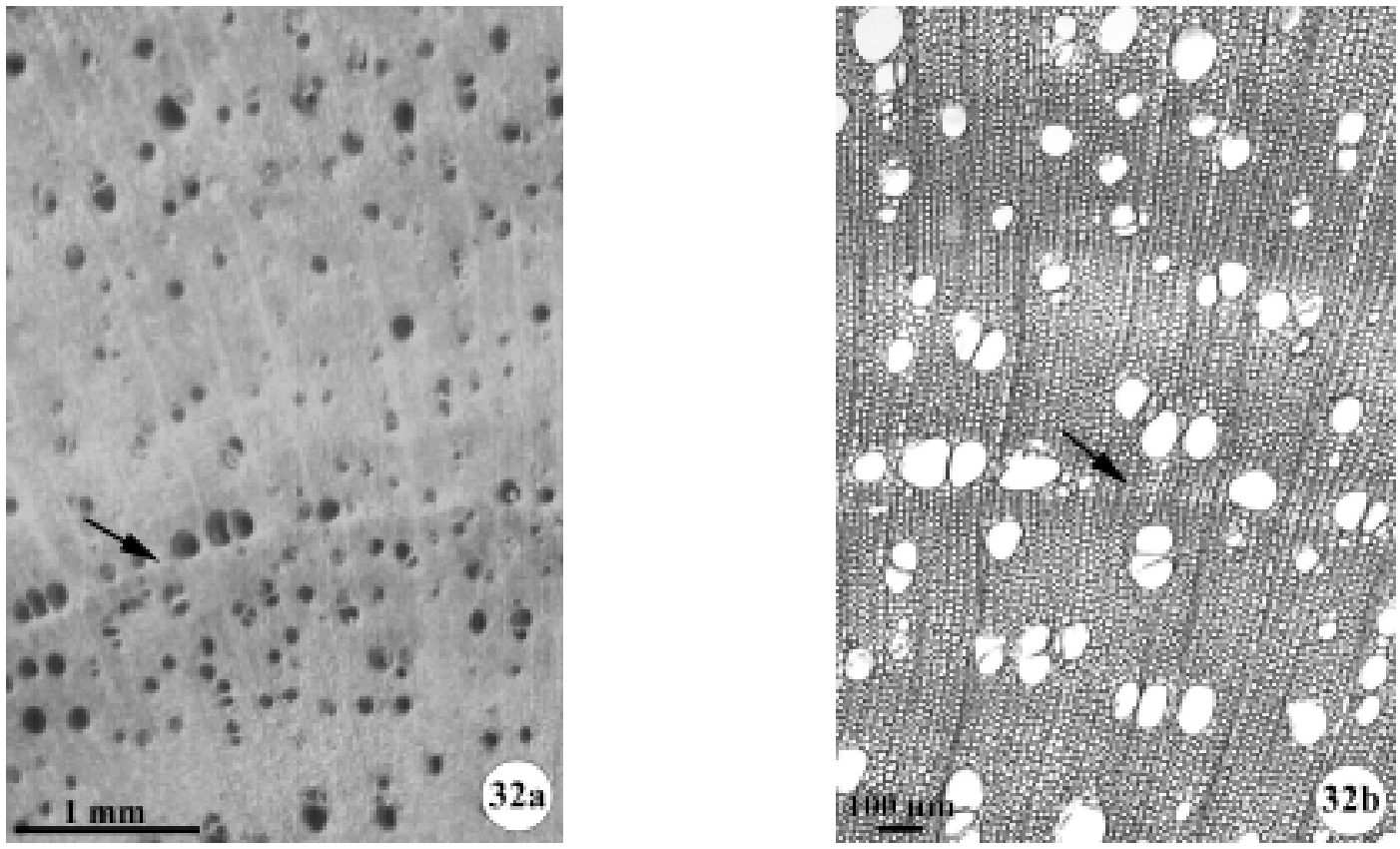

Figure 32. a-b. Transverse section of Aegiphilla sellowiana wood. a) Photomacrograph. Arrow indicates marginal bands of axial parenchyma. b) Photomicrograph. Arrow indicates marginal band of axial parenchyma. 
Marcati, C.R.; Oliveira, J.S. and Machado, S.R. - Biota Neotropica, v6 (n3) - bn00206032006
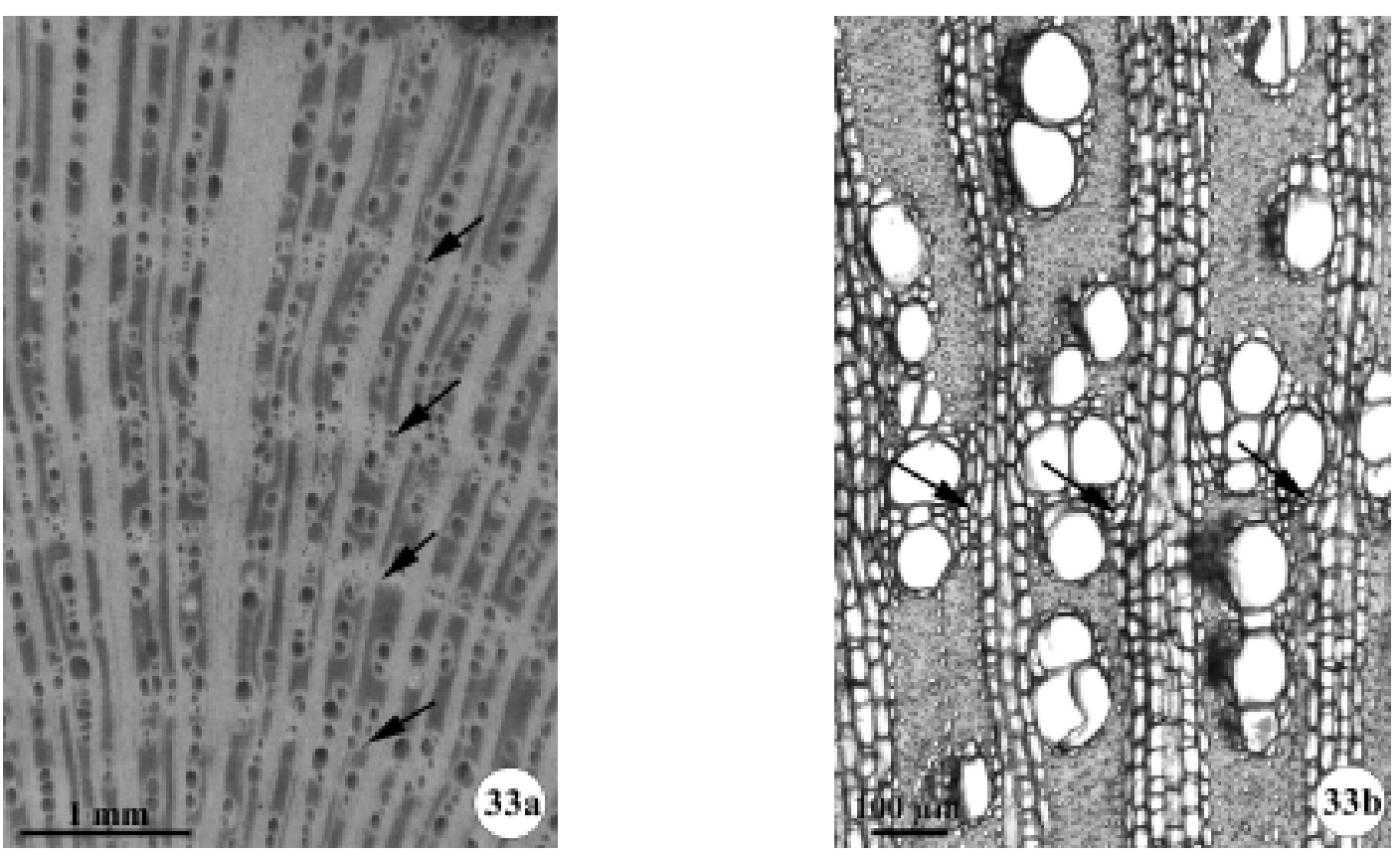

Figure 33. $a-b$. Transverse section of Piptocarpha rotundifolia wood. a) Photomacrograph. Arrows indicate marginal bands of axial parenchyma. Note the higher frequency of vessels adjacent to the marginal bands. $b$ ) Photomicrograph. Arrows indicate distended rays in the boundary of a growth layer.
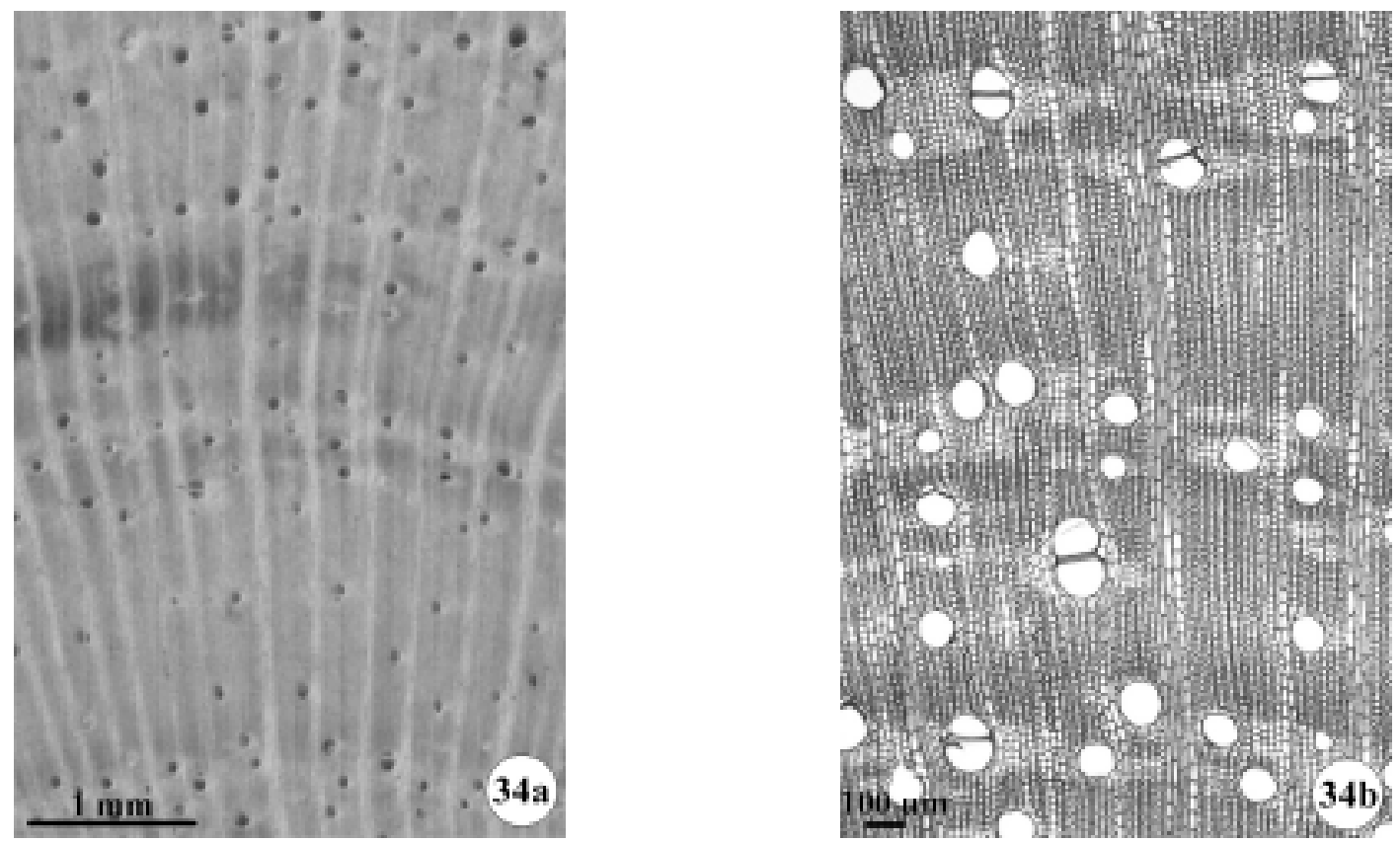

Figure 34. $a-b$. Transverse section of Vochysia rufa wood. a) Photomacrograph. b) Photomicrograph. Note axial parenchyma variation within growth layers.

http://www.biotaneotropica.org.br 
Marcati, C.R.; Oliveira, J.S. and Machado, S.R. - Biota Neotropica, v6 (n3) - bn00206032006
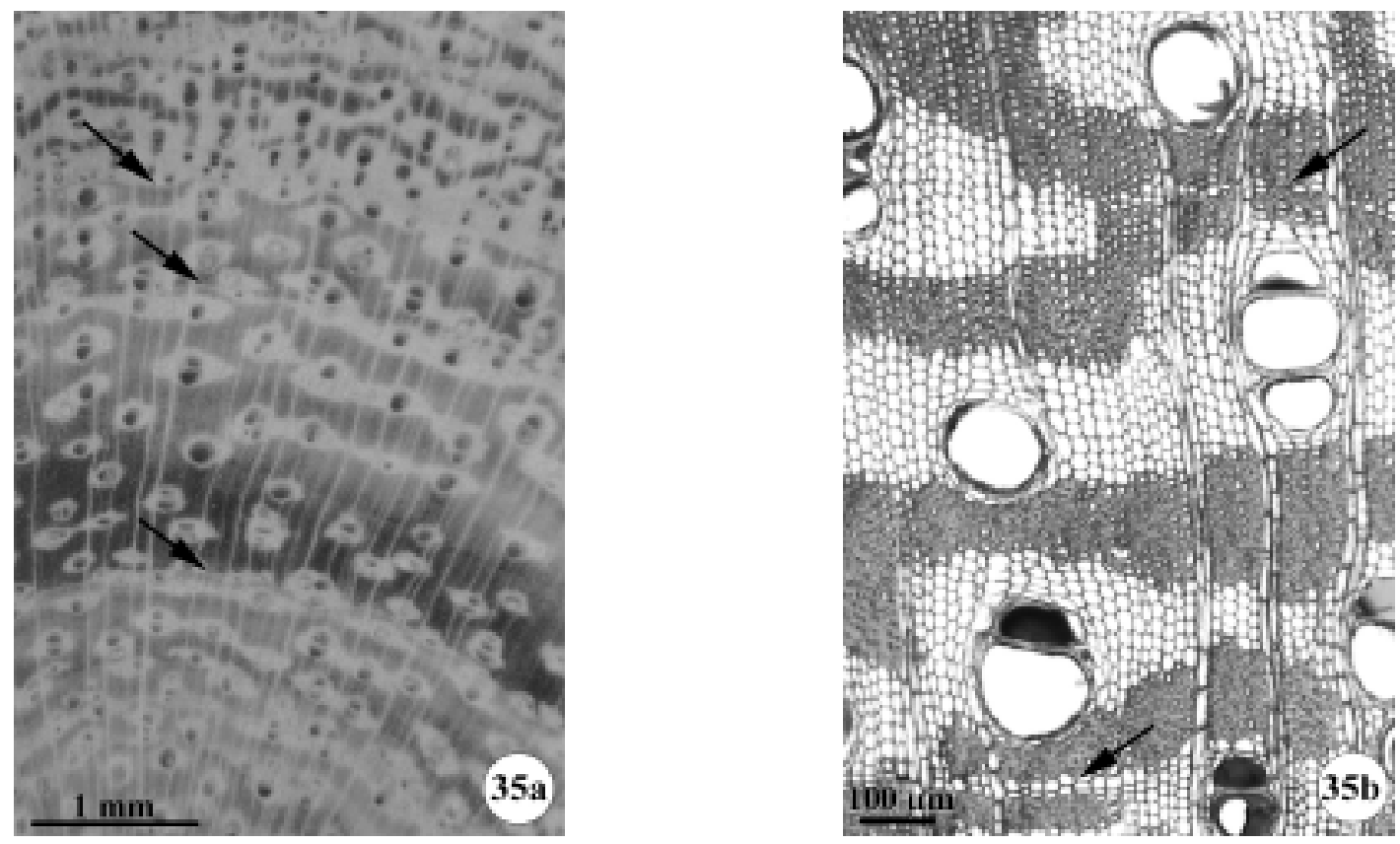

Figure 35. a-b. Transverse section of Dimorphandra mollis wood. a) Photomacrograph. Arrows indicate marginal lines of axial parenchyma. b) Photomicrograph. Arrows indicate marginal lines of axial parenchyma.
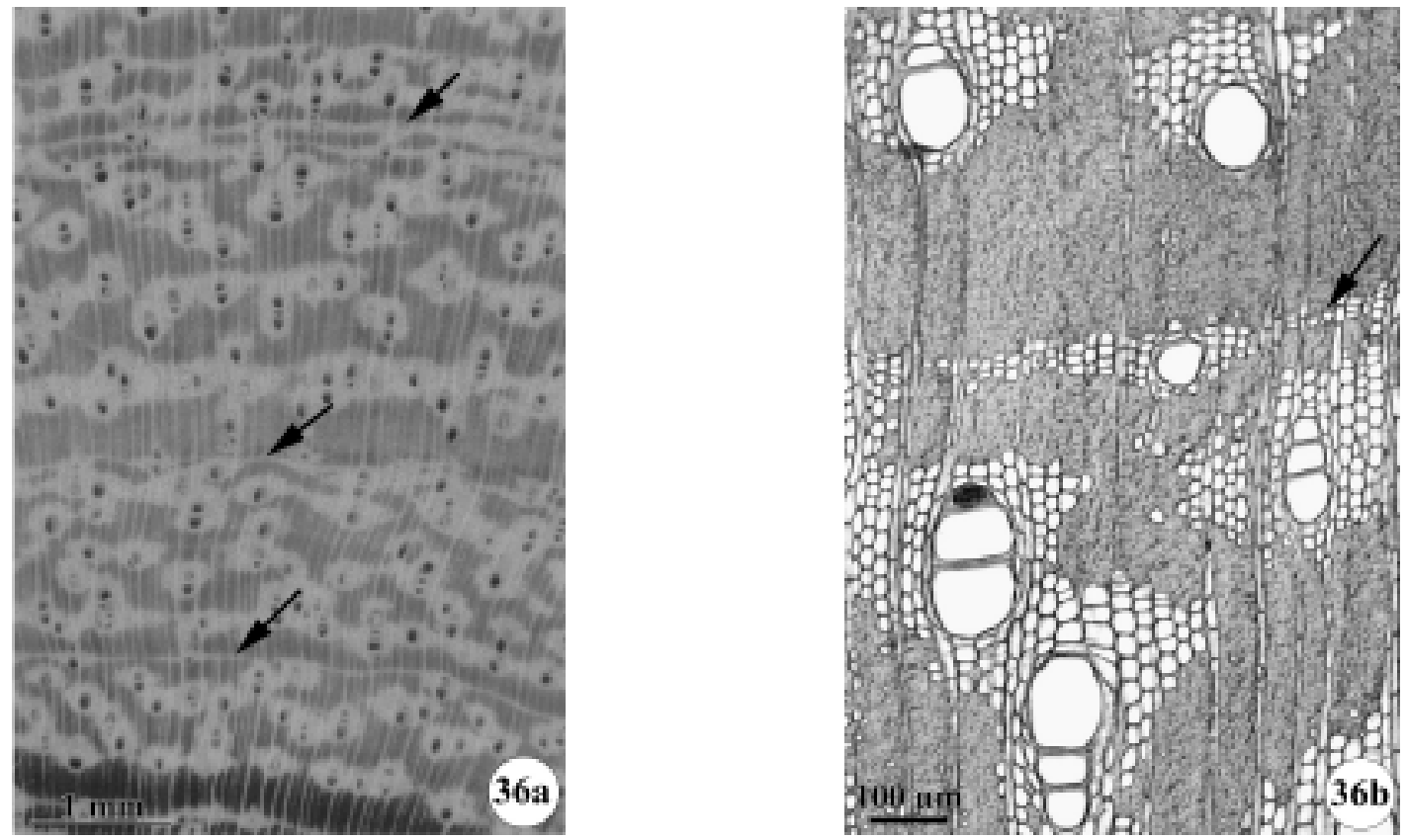

Figure 36. $a-b$. Transverse section of Bowdichia virgiloides wood. a) Photomacrograph. Arrows indicate marginal lines of axial parenchyma. b) Photomicrograph. Marginal lines of axial parenchyma in detail (arrow). 

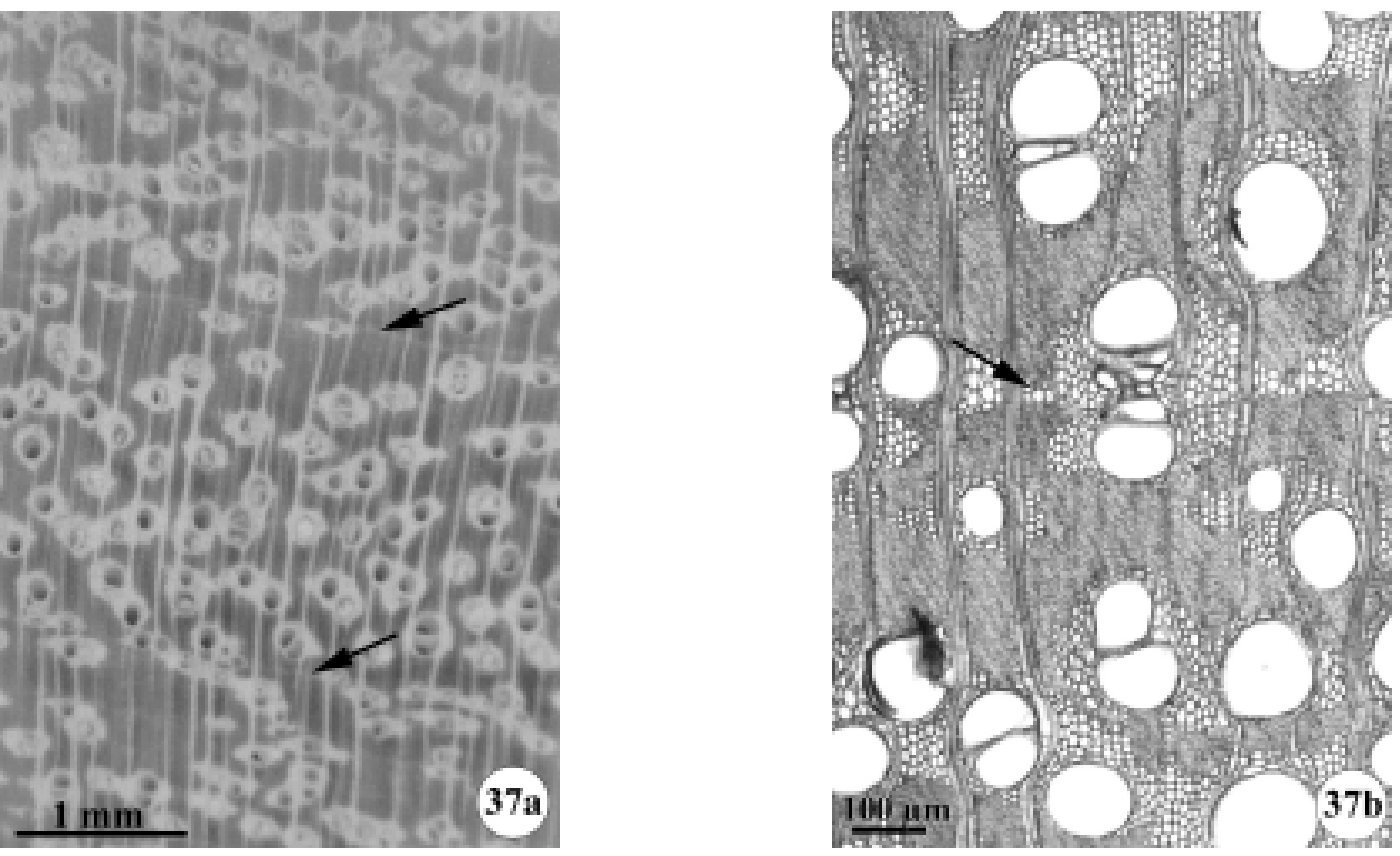

Figure 37. $a-b$. Transverse section of Anadenanthera falcata wood. a) Photomacrograph. Arrows indicate marginal lines of axial parenchyma. b) Photomicrograph. Arrow indicates marginal lines of axial parenchyma in detail.
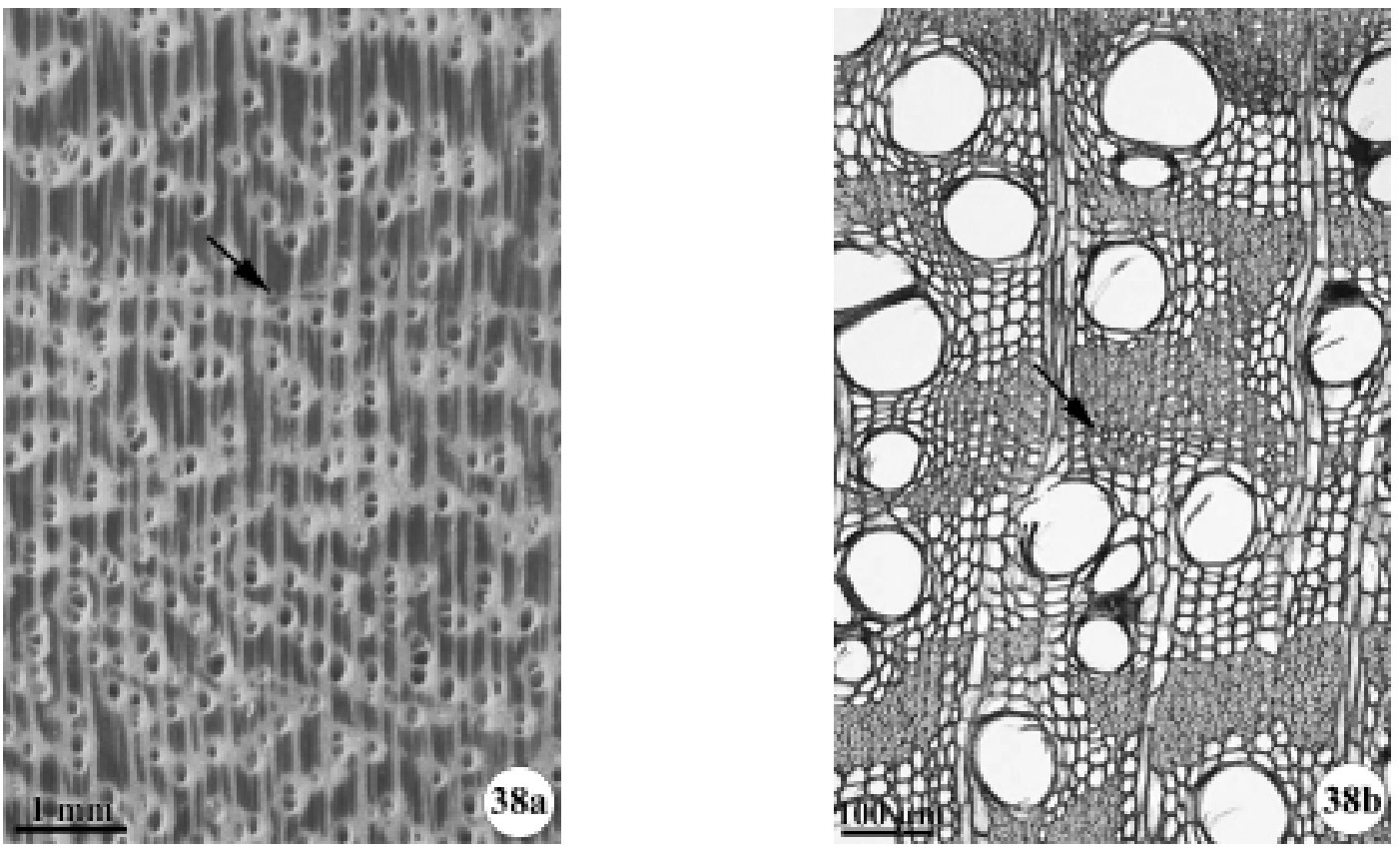

Figure 38. $a-b$. Transverse section of Qualea dichotoma wood. a) Photomacrograph. Arrow indicates marginal lines of axial parenchyma. b) Arrow indicates marginal lines of axial parenchyma in detail.

http://www.biotaneotropica.org.br 
Marcati, C.R.; Oliveira, J.S. and Machado, S.R. - Biota Neotropica, v6 (n3) - bn00206032006
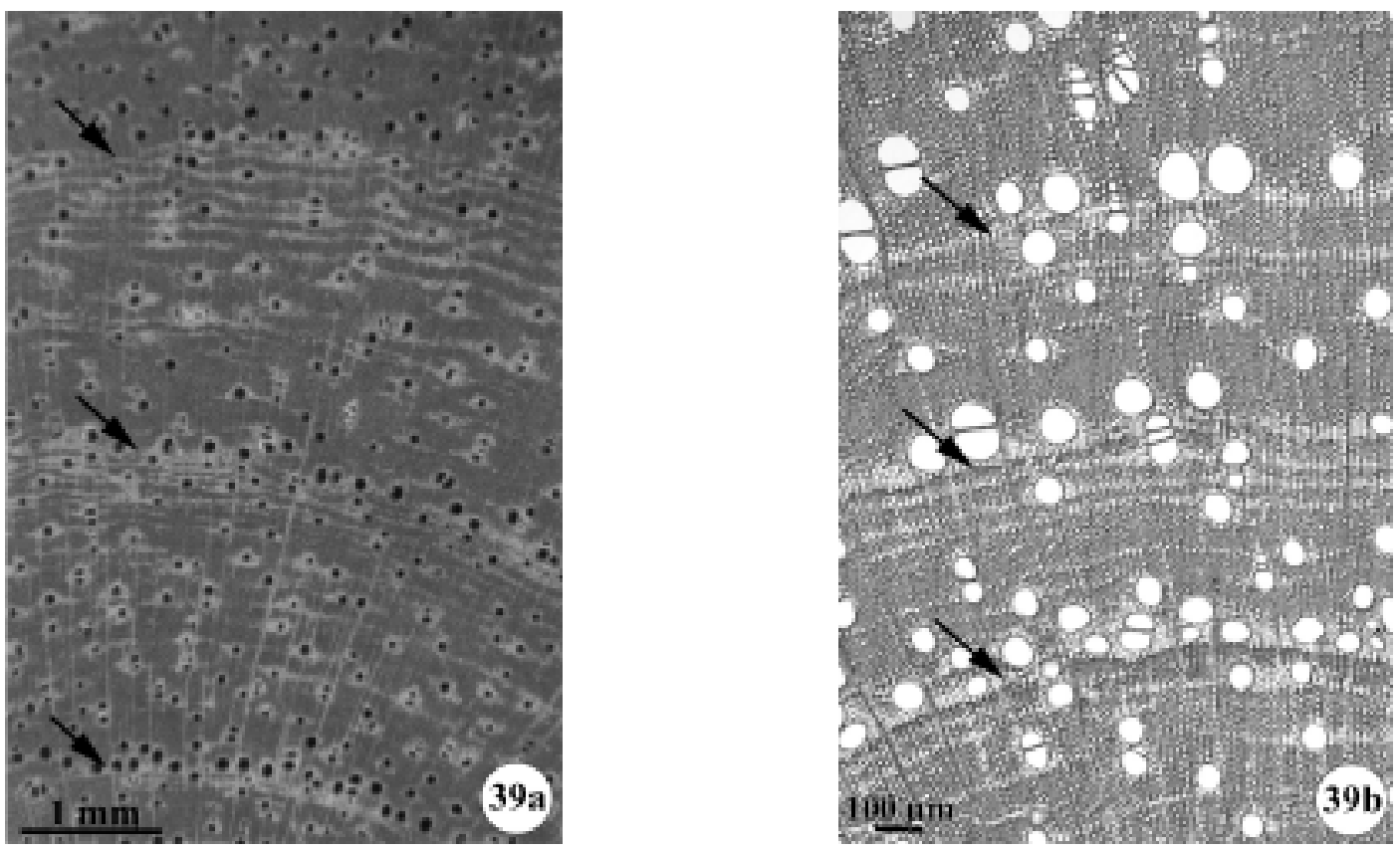

Figure 39. $a-b$. Transverse section of Machaerium villosum wood. a) Photomacrograph. Arrows indicate marginal lines of axial parenchyma. Note the variation within growth layers in the axial parenchyma distribution. b) Photomicrograph. Arrows indicate marginal lines of axial parenchyma.
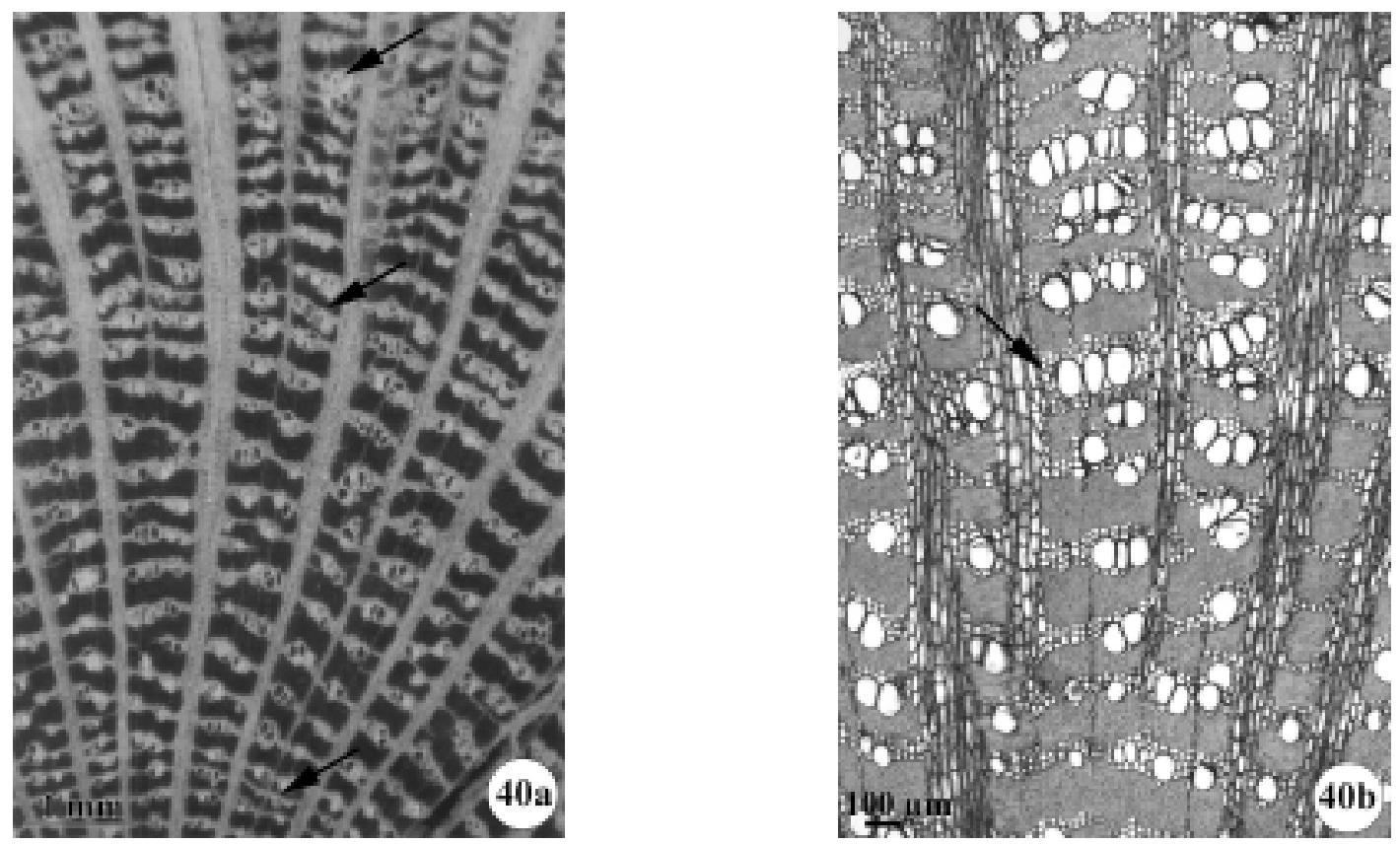

Figure 40. $a-b$. Transverse section of Roupala montana wood. a) Photomacrograph. Arrows indicate closeness of the narrow bands of scalariform parenchyma. b) Photomicrograph. Arrow indicates the region of the closeness of the narrow bands of scalariform parenchyma.

http://www.biotaneotropica.org.br 

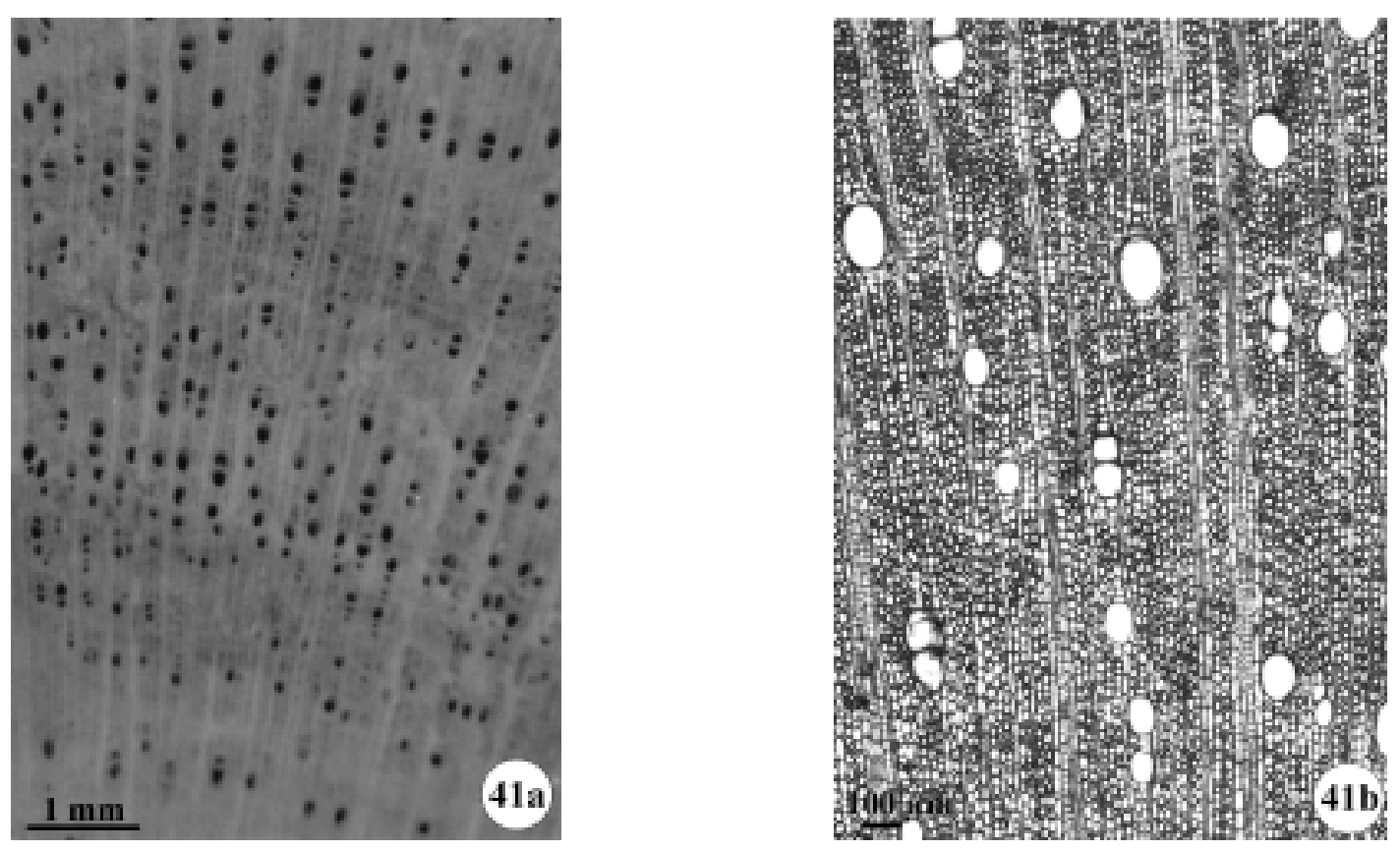

Figure 41. a-b. Transverse section of Luehea grandiflora wood. a) Photomacrograph. Absence of growth ring markers. b) Photomicrograph. 


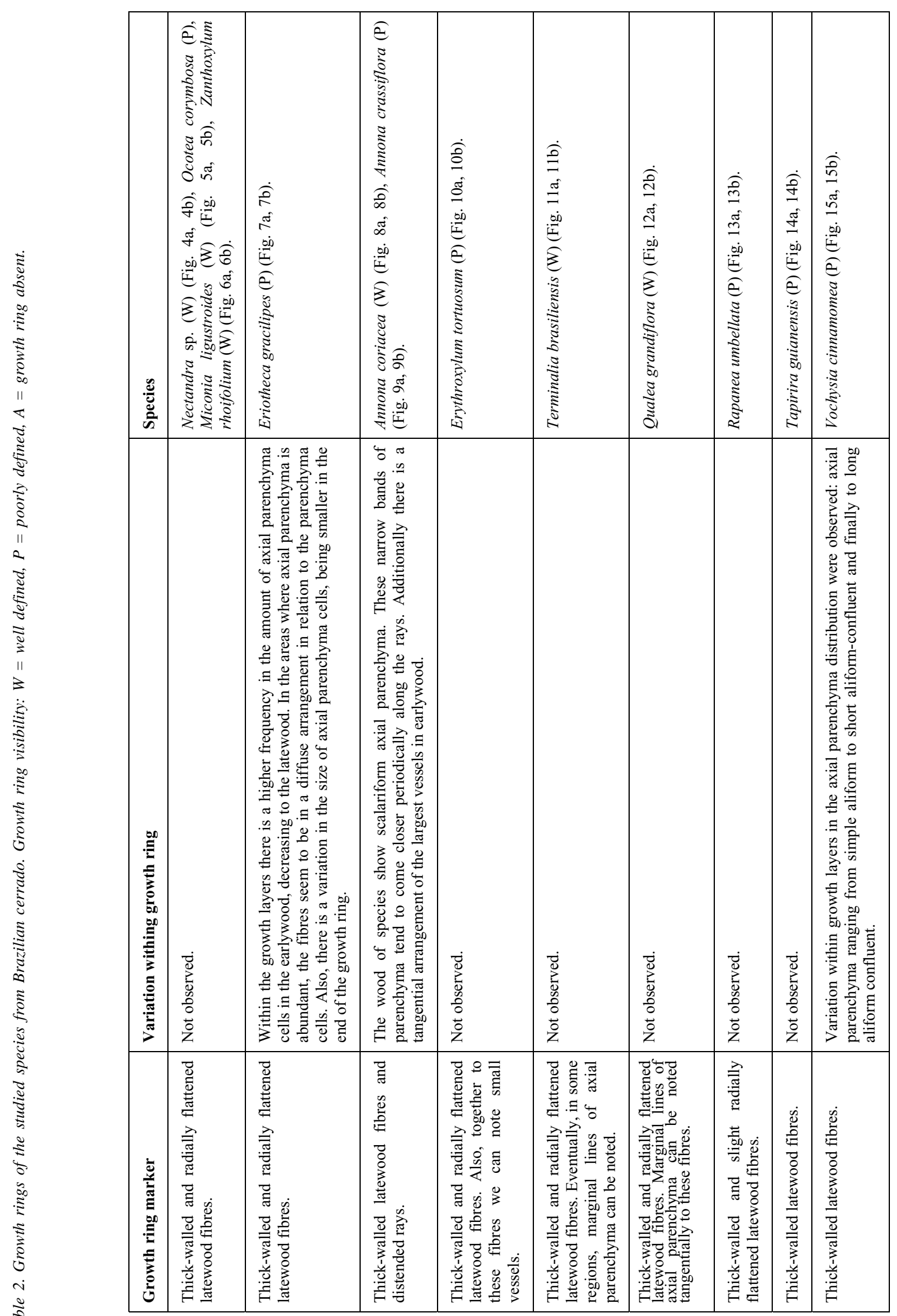

http://www.biotaneotropica.org.br 


\begin{tabular}{|c|c|c|c|c|c|c|c|c|c|c|}
\hline 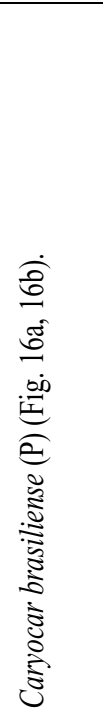 & 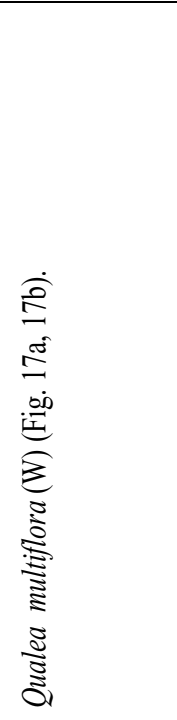 & 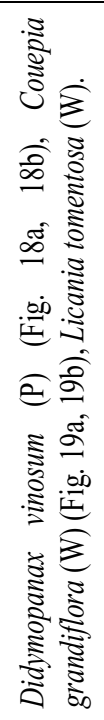 & 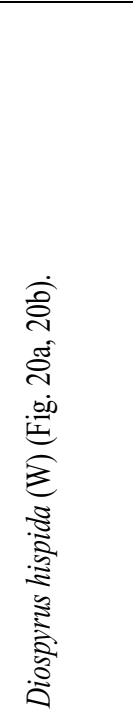 & 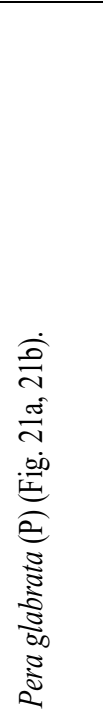 & 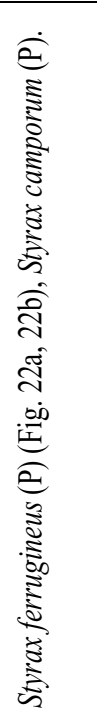 & 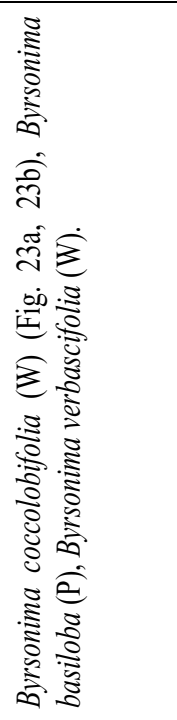 & 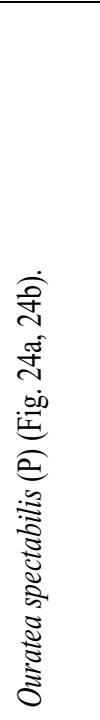 & 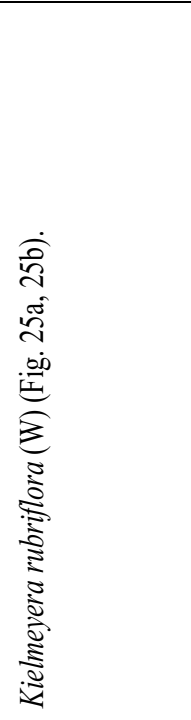 & 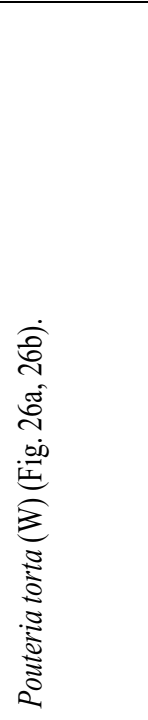 & 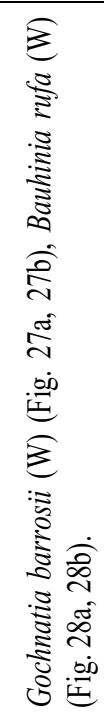 \\
\hline 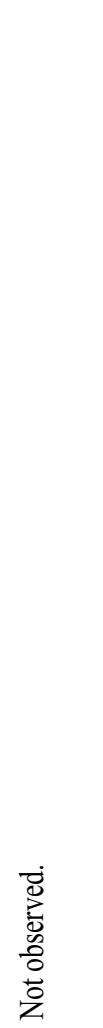 & 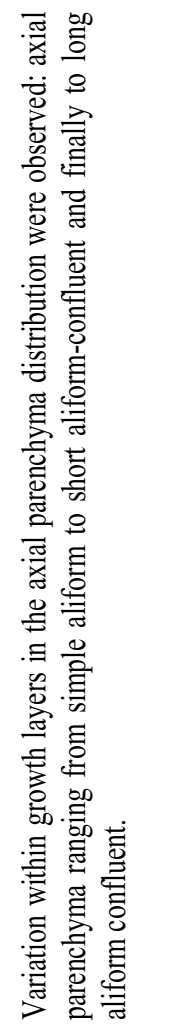 & 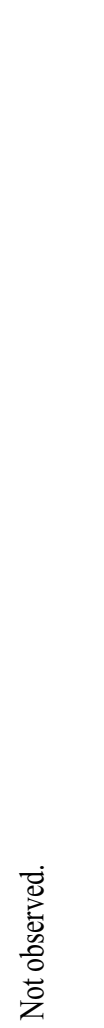 & 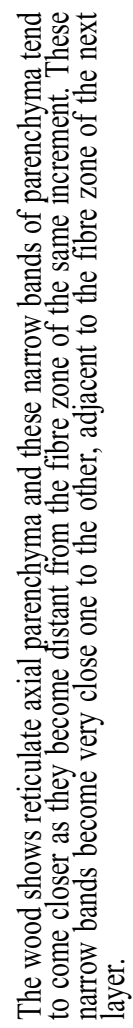 & 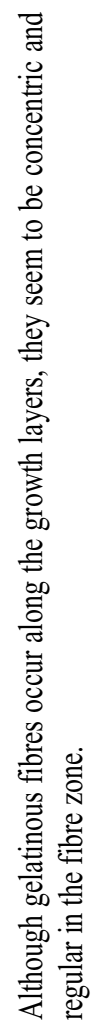 & 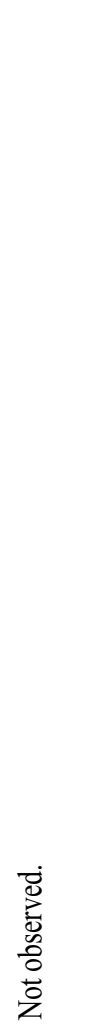 & 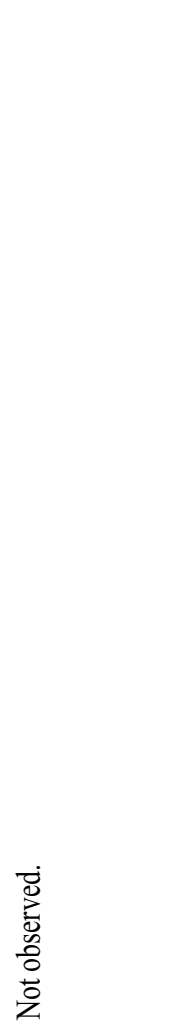 & 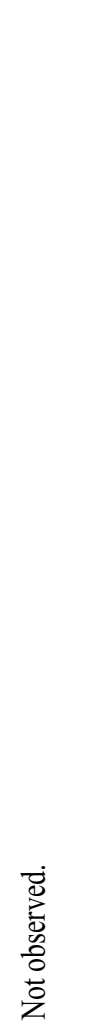 & 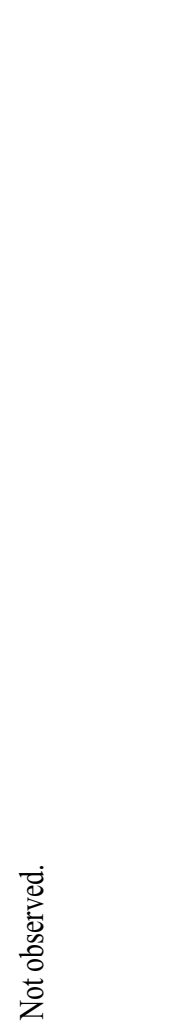 & $\begin{array}{l}\text { Dें } \\
\stackrel{0}{0} \\
0 \\
0 \\
0 \\
0\end{array}$ & 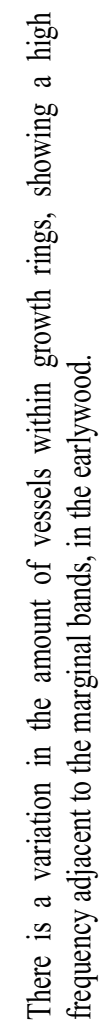 \\
\hline 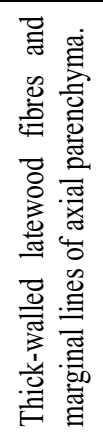 & 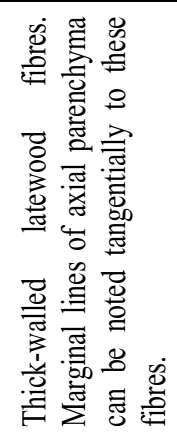 & 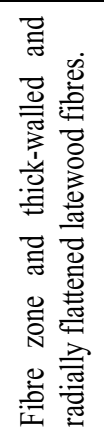 & 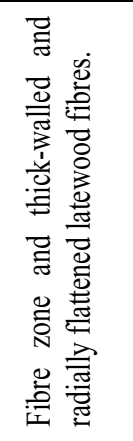 & 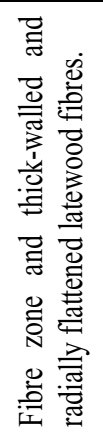 & 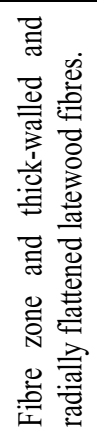 & 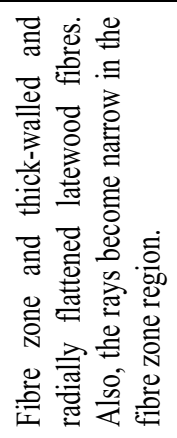 & 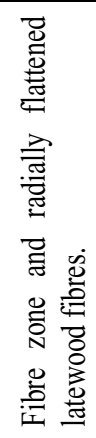 & 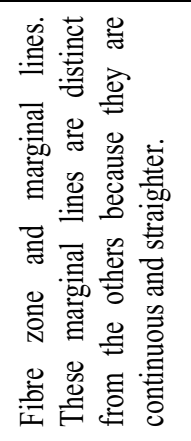 & 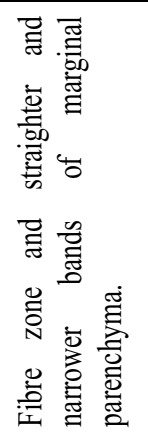 & 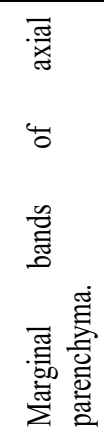 \\
\hline
\end{tabular}




\begin{tabular}{|c|c|c|c|c|c|c|c|c|c|}
\hline 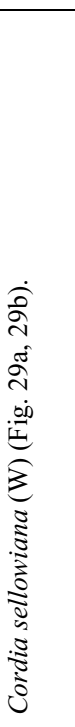 & 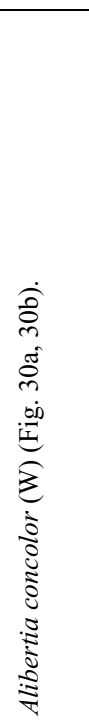 & 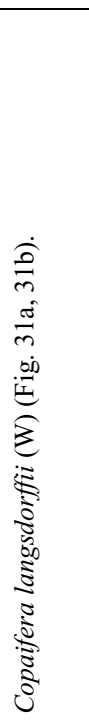 & 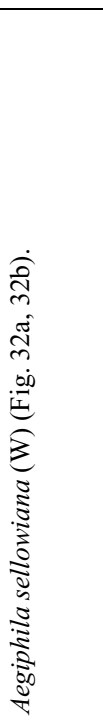 & 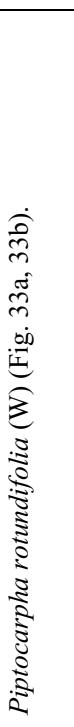 & 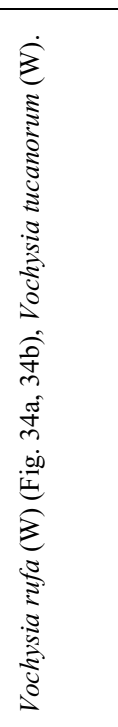 & 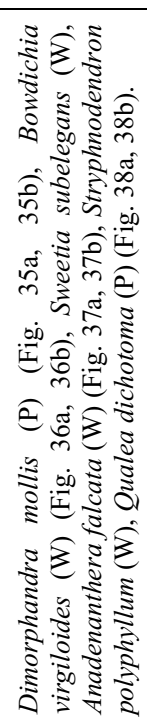 & 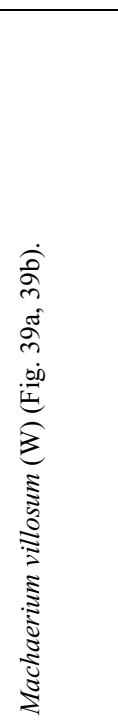 & 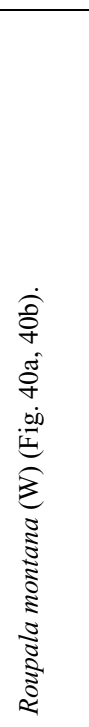 & 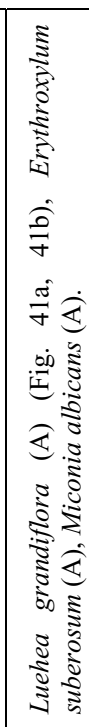 \\
\hline 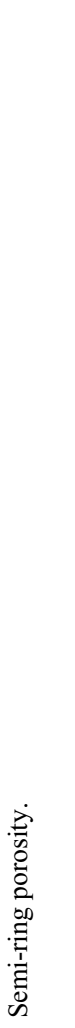 & 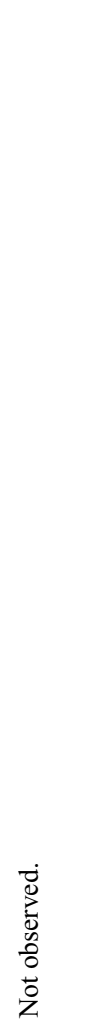 & 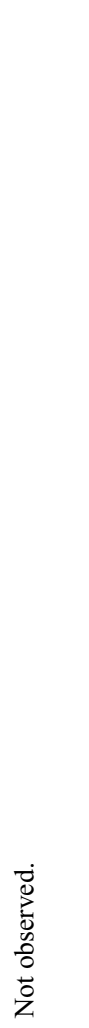 & 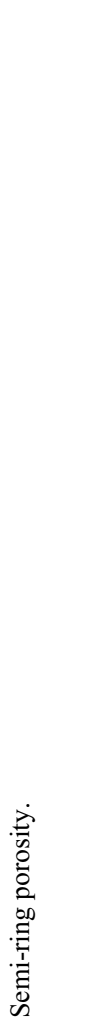 & 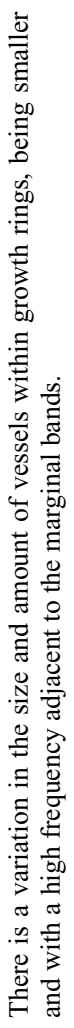 & 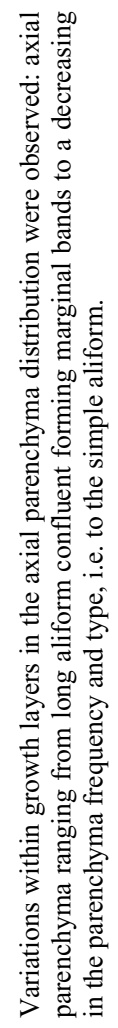 & $\begin{array}{l}\text { D. } \\
\sum_{0}^{0} \\
0 \\
0 \\
0 \\
0 \\
\text { z }\end{array}$ & 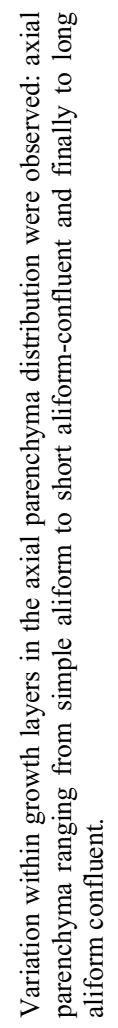 & 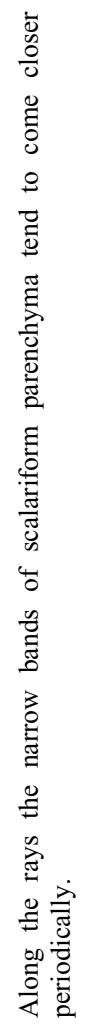 & 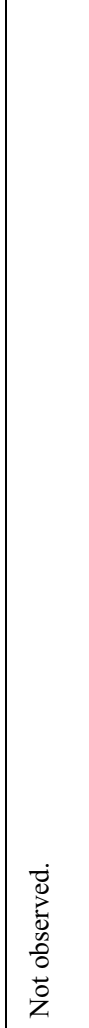 \\
\hline 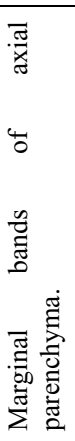 & 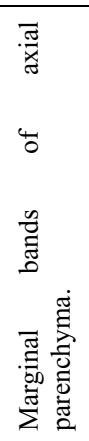 & 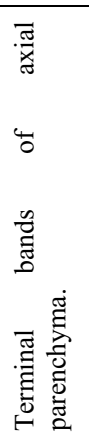 & 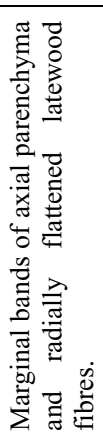 & 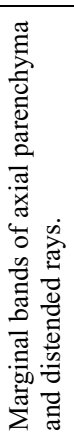 & 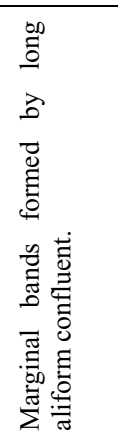 & 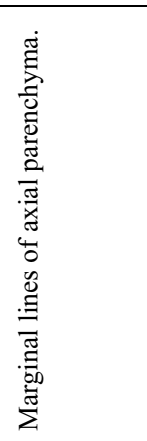 & 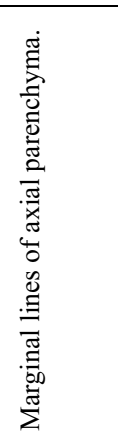 & 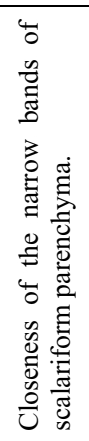 & 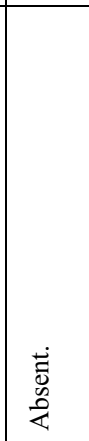 \\
\hline
\end{tabular}


by marginal bands $(20 \%)$, marginal lines $(16 \%)$ and closeness of the narrow bands of scalariform parenchyma (2\%).

In Miconia ligustroides, parenchyma-like fibre bands (lighter regions in macroscopical view) alternating with ordinary fibres (Fig. 5a) were observed.

Within the growth layers, variations in the anatomical features were observed (Table 2), such as: variation in the amount of gelatinous fibres (Fig 21b); variations in the axial parenchyma distribution (Figures 15, 17b, 34, 39); variation in the distance between the narrow bands of axial parenchyma (Figures 8, 9a, 20, 40a); variation in the amount and in the size of axial parenchyma cells (Fig. 7); variation in the size and amount of vessels (Figures 27, 28, 33); semiring porosity (Figures 29, 32).

\section{Discussion}

For this study we were able to analyse $70 \%$ from all wood species that, according to the floristical studies of Bicudo (1987) and Silberbauer-Gottsberger \& Eiter (1983), occur in cerrado areas in the west central of the São Paulo state, Brazil. We noticed that more than $60 \%$ of all species studied showed clearly defined growth rings. This factor should therefore be accounted for conservation and management programs of cerrado, a much threatened vegetation type. This incidence of growth rings in tropical wood species is comparable with $48 \%$ found by Alves \& Angyalossy-Alfonso (2000) in stem wood of 491 Brazilian tropical and subtropical wood species. However, the incidence of growth rings in cerrado species is relatively high if it is compared with the study of Mainieri et al. (1983) who found growth rings in approximately $35 \%$ of the stem wood of nearly 300 Brazilian tropical and subtropical species (see Alves and Angyalossy-Alfonso 2000). The high occurrence of species with growth rings in cerrado might be related to a distinct annual dry season, lasting about one to four months. According to Worbes (1995), a period of two or three months with precipitation below $60 \mathrm{~mm}$ is an environmental condition necessary for species to form growth rings in their wood.

In this study both evergreens and deciduous or semideciduous plants had high ratios of species with growth rings. Similar observations were reported by Alvim (1964) and Worbes (1985) on tropical rain forest trees and by Coradin (2000) for deciduous and evergreens species from cerrado of Brazil Central region. In addition, Coradin (2000) observed that species with a single period of flushing, including the deciduous and some of the evergreen species, showed generally distinct growth rings while those evergreen species which showed more than one period of flushing during the year presented indistinct or poorly defined growth rings. The phenological methodology used in the present study does not allow us to relate growth ring distinctness with flushing periods during the year in a species.
We observed clear differences among tree and shrub species related to both growth rings percentage and distinctness, with attention to trees and tall trees with $100 \%$ of well defined growth rings. The high frequency of small trees and shrubs in cerrado points out the relevance of habit for the analysis of the growth rings formation in this vegetation type.

All combinations of microscopic anatomical features used to detect the growth layers were already mentioned by other authors (Détienne \& Mariaux 1977, Bormann \& Berlyn 1981, Worbes 1985, Carlquist 1988, Baas \& Vetter 1989, IAWA Committee 1989, Fahn \& Werker 1990 and Wheeler \& Baas 1991). Thick-walled and radially flattened latewood fibres and fibre zones boundaring the growth rings were the most common features observed in the wood of the branches of the species studied. Extensive analyses are in course to determine if these markers are predominant in the woody plants of cerrado vegetation.

Marginal bands in Copaifera langsdorffii had already been described by Mainieri et al. (1983) and Détienne \& Jacquet (1993). However, Marcati (2000) studied the formation of these marginal bands and verified that they are terminal since they are formed in the beginning of the dry season, before the cambial dormancy.

The growth ring markers described here agree in general with most of the results obtained by other authors (Mainieri et al. 1983, Détienne 1989, Vetter \& Botosso 1989, Boninsegna et al. 1989, Marcati 2000, Callado et al. 2001) studying stem wood of the same genus or species. Although Mainieri et al. (1983) have described indistinct growth rings in the stem wood of Vochysia spp., Rapanea spp., Qualea spp., Tapirira guianensis, Didymopanax spp. and Roupala spp., and distinct growth rings in the stem wood of Luehea spp., different to our study, it is important to comment that the wood analyzed by Mainieri et al. (1983) were collected from tree stem of different regions of Brazil, so subject to different environmental conditions.

Comparing our results on growth rings markers to those of Coradin (2000) from woody plants from cerrado of Brazil Central region, some differences need further comments. According to this author, Qualea grandiflora and Ouratea hexasperma wood show differences in vessel frequency as the main feature in the boundary of the growth rings in stem and branches, which was not observed neither in Q. grandiflora nor in Ouratea spectabilis studied here. Coradin (2000) did not mention the closeness of the narrow bands of scalariform parenchyma in Roupala montana wood as noted in our study, but a tangential arrangement of vessels in the boundary of growth rings in stem and branches. Didymopanax macrocarpum wood, according to Coradin (2000), shows indistinct growth rings in its branches while in the stem wood the author found a difference in the vessel frequency within growth layers. In Vochysia elliptica wood the author observed fibre zones 
and irregular bands of axial parenchyma in branches and stem wood. The various differences between our study and that of Coradin (2000), listed out above, may be related to the specific environmental conditions of the two cerrados. For instance, unlike the cerrado of São Paulo state, the relative humidity in cerrado from Brazilia can reach very low values during the dry season (see Oliveira \& Marquis 2002).

Parenchyma-like fibre bands alternating with ordinary fibres were observed in Miconia ligustroides wood and it was already mentioned by Coradin (2000) to genus Miconia. These parenchyma-like fibre bands, according to the author, are septate fibres which accumulate starch and so have also a storage function.

Gelatinous fibres, although of common occurrence in most of the studied species, were related to the growth rings, forming a regular pattern, only in Pera glabrata, an evergreen species. Callado et al. (2001) observed random zones of gelatinous fibres throughout the rings in the stem wood of the same species that occur on periodically flooded soil. According to Kozlowski \& Pallardi (1997), gelatinous fibres often extend throughout both earlywood and latewood in evergreen species. Further studies are required to a better comprehension about the differences in the arrangement of gelatinous fibres in Pera glabrata occurring in under different water regime. Gelatinous fibres have been observed in different organs of cerrado plants (Paviani 1978) as a result of reaction wood formation (Kozlowski et al. 1991) and may function as water storage (Paviani 1978, Chalk 1989), as well as giving flexibility to the organ.

Variations in the axial parenchyma distribution in Vochysia cinnamomea, Qualea multiflora, V. rufa, V. tucanorum, wood were reported for the first time. For Machaerium villosum wood this variation had already been reported by Ceccantini (1996). Although Détienne \& Jacquet (1983) have observed long alifom confluent forming bands in the wood of others Vochysia species and terminal parenchyma in other Machaerium species, they did not mention the variation within growth layers as we observed in this study. Variation in the distance between the narrow bands of axial parenchyma periodically along the rays within growth layers in Annona coriacea, A. crassiflora, Diospyrus hispida and Roupala montana wood was also reported for the first time. Variation in the amount of axial parenchyma and in the size of axial parenchyma cells within growth layers in Eriotheca gracilipes was already mentioned by Callado et al. (2001) for E. pentaphylla wood occurring in swamp forests of Rio de Janeiro, Brazil. Variation in the amount of vessels within growth layers was observed in Gochnatia barrosii, Bauhinia rufa and Piptocarpha rotundifolia as described by Coradin (2000) for other cerrado species. Further studies about cambial activity are necessary to a better comprehension about these variations.
Although growth rings occurrence was verified in different cerrado woody species, additional anatomical wood studies of a larger number of species are necessary to determine if the growth rings are annual, widespread and possess taxonomic and/or adaptive value.

\section{Acknowledgements}

We are particularly grateful to Dr. Dirk Koedam for his suggestions, to Clemente José Campos for his help in the field work, to FAPESP (São Paulo Council for Research) - BIOTA Program (Thematic Project Proc. $n^{\circ}$ 00/12469-3 and Proc. $\left.n^{\circ} 03 / 13578-9\right)$, for the financial support of this research, and to CNPq (Brazilian Council for Science and Technology) for research grants to S. R. Machado.

\section{References}

ALVES, E.S. \&ANGYALOSSY-ALFONSO, V. 2000. Ecological trends in the wood anatomy of some brazilian species. I: Growth rings and vessels. IAWA J. 21(1):3-30.

ALVIM, P.T. 1964. Tree growth periodicity in tropical climates. In The formation of wood in forest trees (M.H. Zimmermann, ed.). Academic Press, New York p. 479-495.

BAAS, P. \& VETTER, R.E. 1989. Growth rings in tropical woods. IAWA Bull. 10(2):95-174.

BICUDO, L.R.H. 1987. Mapeamento dos cerrados (sensu lato) do município de Botucatu-SP. Florística de duas áreas. Dissertação de mestrado, Universidade Estadual Paulista, Botucatu.

BONINSEGNA, J.A., VILLALBA, R., AMARILLA, L., OCAMPO, J. 1989. Studies on tree rings, growth rates and age-size relationships of tropical tree species in Misiones, Argentina. In Growth rings in tropical woods (P. BAAS, \& R.E. VETTER, eds.). IAWA Bull. 10(2):161-169.

BORMANN F.H. \& BERLYN, G. 1981. Age and growth rate of tropical trees: new directions of research. Proc. workshop on age and growth rate determination from tropical trees, Harvard Forest, Petersham, Mass p. 1-136.

CALLADO, C.H., SILVA NETO, S.J., SCARANO, F.R., BARROS, C.F. \& COSTA, C.G. 2001. Anatomical features of growth rings in flood-prone trees of the Atlantic rain forest in Rio de Janeiro, Brazil. IAWA J. 22(1):29-42.

CARLQUIST, S. 1988. Comparative wood anatomy: systematic, ecological and evolutionary aspects of dicotyledon wood. Springer-Verlag, Berlin.

CECCANTINI, G. 1996. Anatomia ecológica do lenho de espécies de cerrado e mata: Casearia sylvestris Sw. e Macherium villosum Vog. Dissertação de Mestrado. Universidade de São Paulo, São Paulo. 
CHALK, L. 1989. Fibres. In Anatomy of the dicotyledons. Wood Structure and conclusion of the general introduction. 2. ed. (C.R. Metcalfe \& L. Chalk, eds.). Oxford University Press, Oxford.

CORADIN, V.T.R. 2000. Formação de anéis de crescimento e sazonalidade da atividade cambial de dez espécies lenhosas do cerrado. Tese de Doutorado. Universidade de Brasília, Brasília.

COUTINHO, L.M. 1990. Fire in the ecology of the Brazilian Cerrado. In Fire in the tropical biota. Ecosystem processes and global challenges (J.G. Goldammer, ed.). Springer Verlag, Berlin, p.82-105.

DÉTIENNE, P. 1989. Appearance and periodicity of growth rings in some tropical woods.. In Growth rings in tropical woods (P. BAAS, \& R. E. VETTER, eds.). IAWA Bull. 10(2):123-132.

DÉTIENNE, P. \& JACQUET, P. 1983. Atlas d'identification des bois de l'Amazonie et des régions voisines. Centre Technique Forestier Tropical. Mission Scientifique et Technique du Ministère de l'Industrie et de la Recherche, Nogent-Sur-Marne.

DÉTIENNE, P. \& MARIAUX,A. 1977. Naturé et périodicité des cernes dans les bois rouges de méliacées africaines. Bois For. Trop 175:52-61.

ECKSTEIN, D., SAAS, U., BAAS, P. 1995. Growth periodicity in tropical trees. - Preface. IAWA J. 16:325.

EITEN, G. 1993. Vegetação. In Cerrado: caracterização, ocupação e perspectivas (M.N. Pinto, ed.), $2^{\mathrm{a}}$ ed., Editora Universidade de Brasília, Brasília, p.17-73.

FAHN, A. \& WERKER, E. 1990. Seasonal cambial activity. In The vascular cambium (M. Iqbal, ed.). Research Studies Press Ltd., England, p.139-157.

FRANCO, A.C. 2002. Ecophysiology of woody plants. In The cerrados of Brazil (P.S. Oliveira \& R.J. Marquis, eds.). Columbia University Press, New York, p.178-197.

IAWA COMMITTEE. 1989. List of microscopic features for hardwood identification. IAWA Bull. 10(3):219-332.

KOZLOWSKI, T.T., KRAMER, P.J. \& PALLARDY, S.G. 1991. The physiological ecology of woody plants. Harcourt Brace Jovanovich Publishers, London.

KOZLOWSKI, T.T. \& PALLARDY, S.G. 1997. Growth control in woody plants. Academic Press, California.

MACHADO, S.R., ANGYALOSSY-ALFONSO, V. \& MORRETES, B.L. 1997. Comparative wood anatomy of root and stem in Styrax camporum (Styracaceae). IAWA J. 18(1):13-25.

MACHADO S.R. \& ANGYALOSSY-ALFONSO, V.. 1995. Ocurrence of perforated ray cells in wood of Styrax camporum Pohl. (Styracaceae). Rev. bras. Bot. 18(2):221-225.
MACHADO, S.R., RODELA, R.A., ANGYALOSSY, V. \& MARCATI, C.R. (in press). Structural variations in root and stem wood of Styrax L. (Styracaceae) from forest and cerrado. IAWA J.

MAINIERIC., CHIMELO, J.P. \&ANGYALOSSY-ALFONSO, V. 1983. Manual de identificação das principais madeiras comerciais Brasileiras. Promocet, Instituto de Pesquisas Tecnológicas, São Paulo.

MARCATI, C.R. 2000. Sazonalidade cambial em espécies tropicais. Tese de doutorado. Universidade de São Paulo, São Paulo.

MARCATI, C.R., ANGYALOSSY-ALFONSO, V. \& BENETATI., L. 2001. Anatomia comparada do lenho de Copaifera langsdorffii Desf. (LeguminosaeCaesalpinoideae) de floresta e cerradão. Braz. J. Bot. 24(3):311-320.

MORRETES, B.L. de, \& FERRI, M.G. 1959. Contribuição ao estudo da anatomia das folhas de plantas do cerrado. Bolm. Fac. Fil. Cienc. Letr. Univ. S. Paulo 243(16):7-70.

MORRETES, B.L. de. 1967. Contribuição ao estudo da anatomia das folhas de plantas do cerrado II. Bolm. Fac. Fil. Cienc. Letr. Univ. S. Paulo 22:207-224.

MORRETES, B.L. de. 1969. Contribuição ao estudo da anatomia das folhas de plantas do cerrado III. Bol. Bot. Univ. S. Paulo 331(24):7-32.

OLIVEIRA, P.S. \& MARQUIS, R.J. 2002. The cerrados of Brazil. Columbia University Press. New York.

PAVIANI, T.I. 1978. Anatomia vegetal e cerrado. Ciênc. Cult. 30(9):1076-86.

RIBEIRO, J.E.L.S., HOPKINS, M.J.G., VICENTINI, A., SOTHERS, C.A., COSTA, M.A.S., BRITO.J.M., SOUZA, M.A.D., MARTINS, L.H.P., LOHMANN, L.G., ASSUNÇÃO, P.A.C.L., PEREIRA, E.C., SILVA, C.F., MESQUITA, M.R., PROCÓPIO, L.C. 1999. Flora da reserva Ducke: guia de identificação das plantas vasculares de uma floresta de terra-firme na Amazônia Central. Manaus: INPA, DFID.

ROESER, K.R. 1972. Die nadel der Schwarzkiefermassenprodukt und kunstwerk der natur. Mikrokosmos 61(2):33-36.

SILBERBAUER-GOTTSBERGER, I. \& EITEN, G. 1983. Fitossociologia de um hectare de cerrado. Brasil Florestal 54(13):55-71.

SOUZA, V.C. \& LORENZI, H. 2005. Botânica sistemática: guia ilustrado para identificação das famílias de angiospermas da flora brasileira, baseado em APGII. Nova Odessa, Instituto Plantarum de Estudos da Flora Ltda.

TOMAZELLO, M., LISI, C.S., HANSEN, N. \& CURY, G. 2004. Anatomical features of increment zones in different tree species in the State of São Paulo, Brazil. Scientia Forestalis 66 (dez):46-55. 
VETTER, R.E. \& BOTOSSO, P.C. 1989. Remarks on age and growth rate determination of Amazonian trees. In Growth rings in tropical woods (P. BAAS, \& R.E. VETTER, eds.) IAWABull. 10(2):133-145..

WHEELER, E. \& BAAS, P. 1991. A survey of the fossil record for dicotyledonous wood and its significance for evolutionary and ecological wood anatomy. IAWA Bull. 12(3):275-332.

WALTER, H., HARNICKELL, E., MUELLER-DOMBOIS, D. 1975. Climate diagram maps. Springer-Verlag, Berlim.

WORBES, M. 1985. Structural and other adaptations to longterm flooding by trees in Central Amazonia. Amazoniana 9(3):459-484.

WORBES, M. 1995. How to measure growth dynamics in tropical trees. A review. IAWA J. 16(4):337-351.

Title: Growth rings in cerrado woody species: occurrence and anatomical markers.

Authors: Marcati, C.R.; Oliveira, J.S. and Machado, S.R.

Biota Neotropica, Vol. 6 ( number 3): 2006

http://www.biotaneotropica.org.br/v6n3/pt/ abstract?article+bn00206032006

Date Received 08/082005 - Revised 08/18/2006

Accepted 09/01/2006

ISSN 1676-0611

http://www.biotaneotropica.org.br 